\title{
Organophosphorus Compounds as Chemical Warfare Agents: a Review
}

\author{
Reinaldo T. Delfino, Tatiana S. Ribeiro and José D. Figueroa-Villar* \\ Seção de Engenharia Química, Instituto Militar de Engenharia, Praça Gen Tibúrcio, 80, \\ Praia Vermelha, 22290-070 Rio de Janeiro-RJ, Brazil
}

Os agentes de guerra química constituem uma das maiores ameaças do mundo moderno. Dentre estes, destacam-se os agentes neurotóxicos, em virtude de sua alta letalidade e periculosidade. Eles são compostos organofosforados que atuam pela inibição da enzima acetilcolinesterase, a qual é fundamental no processo de transmissão de impulsos nervosos. Existem várias formas de tratamento para a intoxicação por organofosforados, mas nenhuma delas é eficaz contra todos os agentes conhecidos ou contra todos os seus efeitos. Esta revisão tem como foco o uso de compostos organofosforados como agentes neurotóxicos de guerra química. Após uma breve introdução histórica, será feita uma discussão sobre as principais características estruturais e biológicas da acetilcolinesterase, seguida por uma revisão das propriedades dos compostos organofosforados e da sua aplicação como agentes de guerra química. Por fim, serão discutidas as formas de tratamento contra estes agentes, com ênfase nas oximas usadas para reativar a acetilcolinesterase inibida.

Chemical warfare agents constitute one of the greatest threats in the modern world. Among them, the neurotoxic agents are of special interest due to their high lethality and danger. Neurotoxic agents are organophosphorus compounds that act by inhibiting the enzyme acetylcholinesterase, which is fundamental for the control of transmission of nervous impulses. There are several ways of treating intoxication by organophosphorus compounds, but none of them is efficient against all the known neurotoxic agents or against all of their effects. This review focus on the use of organophosphorus compounds as neurotoxic chemical warfare agents. After a brief historical introduction, it will be done a discussion about the structural and biological characteristics of acetylcholinesterase, followed by a review of the properties of organophosphorus compounds and their application as chemical warfare agents. Finally, the ways of treatment against intoxication with these agents will be discussed, with emphasis on the oximes used for reactivating the inhibited acetylcholinesterase.

Keywords: chemical warfare agents, organophosphorus compounds, acetylcholinesterase, oximes, neurotoxic agents

\section{Introduction}

One of the greatest threats in modern world is the possibility of use of chemical weapons by regular forces or by terrorist groups. Among these weapons, the socalled neurotoxic agents, commonly known as "nerve agents", constitute the greatest concern, due to their highly deleterious effects on humans. The potentiality of attacks employing these agents gives a strong reason for continuous research on the development of more effective antidotes against them.

One way of treating victims of nerve agents consists on the administration of certain pyridinic oximes, which

\footnotetext{
*e-mail: figueroa@ime.eb.br
}

possess the capacity to regenerate the catalytic activity of the enzyme acetylcholinesterase (AChE), the target of these compounds. ${ }^{1-4}$ Unfortunately, until now it has not been reported any oxime that acts efficiently against all the existing neurotoxic agents. Therefore, oximes that are efficient for the treatment of intoxication with one specific nerve agent can be completely ineffective with another. ${ }^{1-4}$ Also, even the fast identification of a neurotoxic agent in order to choose the treatment for the intoxication is usually not rapid enough to either save the life of the patient or to avoid serious permanent damages.

In this review, the main aspects concerning the nature and mode of action of neurotoxic agents and the treatment of intoxicated patients are discussed. 


\section{History and Classification of the Chemical War Agents}

The expression "chemical warfare", first used in 1917, refers to all tactical war assets which use incendiary mixtures, smokes and irritating, vesicant, poisonous or asphyxiating gases. ${ }^{5}$ For the Brazilian Army, chemical war is the one that utilizes substances designated as "chemical agents", which are defined as all the compounds that, due to their chemical activity, generate a toxic, smoking or incendiary effect, when used for military purposes. ${ }^{6}$ Chemical warfare agents (CWAs) distinguish themselves from biological warfare agents, since the latter consist of microorganisms which cause diseases in humans, animals or plants, or which deteriorate different materials. ${ }^{5}$ Microorganisms toxins may be considered as intermediate between chemical and biological warfare agents, since they are chemical entities which are produced exclusively by living organisms. However, it is not uncommon to consider them as biological weapons. ${ }^{5}$

The use of CWAs can be retraced to 1,000 B.C., when the Chinese employed smokes containing arsenic, while the Greek utilized chemical compounds to poison water and other supplies of their enemies. In the following centuries, the use of CWAs was diversified, progressively becoming more sophisticated. ${ }^{5}$ Today it is considered that modern chemical war began during the First World War, more precisely on April 22 $2^{\text {nd }} 1915$, when the German Army employed large quantities of chlorine gas against the Allied Forces in Ypres, Belgium. British and French troops equally retaliated, and the First World War became the first stage of the use in large scale of several poisonous gases, some of which, like phosgene, diphosgene, hydrogen cyanide, cyanogen chloride and mustard gas, were even more toxic than chlorine,. Since then, the use of CWAs was confirmed or suspected in several localized conflicts, although never in such scale as in World War I. ${ }^{5}$ Some of the main historical events involving CWAs in the $20^{\text {th }}$ century are listed in Table $1 ., 7$

Although Japan used CWAs against the Chinese forces between the end of the 1930's and the beginning of the 1940 's, it is interesting to note that there is no confirmation of the use of these weapons in Europe during World War II. This fact is astonishing, since Germany was much more advanced in that area than the Allies, to whom tabun, sarin and soman were completely unknown. ${ }^{8}$ The reasons for the non-utilization of these neurotoxic agents by Germany is still a matter of debate: some people argue that Adolph Hitler or German senior officers, themselves victims of CWAs during World War I, would have prohibited the use of chemical weapons. However, the most probable reason was the German fear that the United States and Great Britain
Table 1. Historical facts about the modern use of chemical weapons

\begin{tabular}{ll}
\hline Date & Historical fact \\
\hline $1915-18$ & Use of chemical weapons in World War I. \\
1935 & Italy uses mustard gas in Libya and Ethiopia. \\
1936 & $\begin{array}{l}\text { The German chemist Gerhard Schrader synthesizes the } \\
\text { neurotoxic agent tabun. }\end{array}$
\end{tabular}

1937 Schrader and coworkers synthesize the neurotoxic agent sarin.

1939 Japan uses mustard gas against China.

1940-5 Germany employs Zyklon B, a variant of hydrogen cyanide, in gas chambers.

1942 Germany begins the industrial production of nerve gases in Dyhenfurth.

1944 The German chemist Richard Kuhn synthesizes the neurotoxic agent soman.

1950's VX is synthesized by the British and weaponized by the Americans.

1984-6 The use of CWAs by Iraq in the war against Iran is confirmed.

1988 The use of chemical weapons by Iraq in the repression against the Kurdish population situated in the North of the country is confirmed.

1994 Terrorist attack with sarin in Matsumoto, Japan, executed by the Aum Shinrikyo sect, results in 7 deaths and more than 300 injured.

1994/5 Assassination attempts with VX are made in Osaka, Japan, by Aum Shinrikyo members, with one fatality.

1995 Aum Shinrikyo uses sarin to attack the Tokyo subway, causing 12 deaths and thousands of casualties.

possessed equal or similar chemical weapons (which was untrue) and would use them in retaliation. ${ }^{9}$

Military CWAs can be classified in several categories, according to the nature of their use, their persistence in the field and their physiological action. ${ }^{10}$ They are generally divided in the following classes: (i) VESICANTS, which are compounds that cause irritation and vesication of the skin and mucous membranes (mainly the lungs), being the mustard gases $\left(\mathrm{ClCH}_{2} \mathrm{CH}_{2} \mathrm{XCH}_{2} \mathrm{CH}_{2} \mathrm{Cl}, \mathrm{X}=\mathrm{O}, \mathrm{S}, \mathrm{NR}\right)$ the most important representatives of the group. Although they can lead to death, vesicants usually have only an incapacitating effect, as the victims of mustard gas require one to four months of hospitalization, for instance. (ii) PULMONARY TOXICANTS, which are compounds that attack the respiratory tract, causing choking. The main substances of this class are phosgene $\left(\mathrm{COCl}_{2}\right)$ and diphosgene $\left(\mathrm{Cl}_{3} \mathrm{COCOCl}\right)$. (iii) CYANIDES, which are substances that release cyanide ions in the body, being hydrogen cyanide and cyanogen chloride the most used. The major mechanism of toxicity of cyanides occurs by inhibition of cytochrome c oxidase, a process that results into cytotoxic hypoxia. ${ }^{11}(i v)$ INCAPACITATING 
AGENTS, also known as irritating agents, are compounds that produce physiological or mental effects, rendering their victims unable to perform their duties. The most remarkable among them are the tear gases (chloroacetophenone, o-chlorobenzylidenemalononitrile, bromoacetone, etc.) and the vomiting gases (like chloropicrin, $\mathrm{Cl}_{3} \mathrm{CNO}_{2}$ ) and psychoactive agents like 3-quinoclinidinyl benzilate (BZ). (v) NEUROTOXIC AGENTS, which are also known as nerve agents or nerve gases, inhibit an enzyme called acetylcholinesterase, causing several deleterious effects which can lead to death. The most important ones are tabun, sarin, soman and VX.

The employ of chemical warfare in conflicts is strongly objected by the majority of mankind; perhaps only biological warfare provokes a repulse even larger. ${ }^{8}$ Despite the successful United Nations efforts to proscribe these weapons, summarized by adherence to the Chemical Weapons Convention by most country of the world, ${ }^{12}$ the possibility of chemical warfare use by rogue States or by terrorist groups is still a great concern.

Nerve agents, the focus of this review, are among the most toxic synthetic compounds and, along with vesicants, constitute the majority of the modern chemical arsenals. ${ }^{10}$ As already discussed, tabun, sarin and soman were synthesized, but not employed, during World War II. VX was synthesized in Great Britain during the 1950's and later developed for military purposes by U.S.A. ${ }^{3}$ Nerve agents are synthesized easily and cheaply, are easily dispersed and difficult to detect, feared by public opinion and highly lethal, being a excellent weapon for terrorist purposes. ${ }^{13}$ Although there are several unconfirmed reports of nerve agents' utilization since $1967,{ }^{5}$ there are fortunately few confirmed cases of their use. During the Iran-Iraq war, Iraq occasionally employed tabun and, possibly, other nerve agents, along with mustard gas. ${ }^{14,15}$ Iraq has also used sarin and mustard gas against the civilian Kurdish village of Birjinni, in 1988. ${ }^{16}$ Impure sarin has been employed in the terrorist attacks in the Japanese cities of Matsumoto (1994) and Tokyo (1995) perpetrated by the Aum Shirinkyo sect. ${ }^{3,17-20}$ Finally, there are records of assassination attempts employing VX. ${ }^{21}$

To further discuss the neurotoxic agents, it is necessary to review the main characteristics of their target, the acetylcholinesterase enzyme.

\section{Acetylcholinesterase}

\subsection{The cholinesterases}

Acetylcholinesterase (AChE, E.C. 3.1.1.7) and butyrylcholinesterase (BChE, E.C. 3.1.1.8) are the enzymes which constitute the group of the cholinesterases. Acetylcholinesterase hydrolyses acetylcholine (ACh) and is mainly associated to nerves and muscles, being typically found on the synapses, while butyrylcholinesterase, also known as plasma cholinesterase or pseudocholinesterase, hydrolyses butyrylcholine and is synthesized by the liver, being found in large amounts in the serum. The first structure of a cholinesterase was determined in $1986^{22}$ and after that it became clear that these enzymes define a unique family of serine hydrolases. ${ }^{23,24} \mathrm{AChE}$ and $\mathrm{BChE}$ distinguish from each other mainly in the specificities of hydrolysis of different cholines: AChE hydrolyses ACh quickly, propionylcholine slower, and shows a marked loss of hydrolytic activity for butyrylcholine, while $\mathrm{BChE}$ is less selective to the size or nature of the acyl group of the choline to be hydrolyzed, hydrolyzing butyrylcholine and benzoylcholine efficiently. ${ }^{23,25}$ These unequal specificities are explained by differences in the sequences of the enzymes, which result in different sizes of their active sites. ${ }^{25,26}$

Both $\mathrm{AChE}$ and $\mathrm{BChE}$ are found in neurons and glial cells of the human brain. ${ }^{27}$ The physiological function of $\mathrm{BChE}$ is not fully understood yet: it appears not to be essential to cholinergic transmission, but there are some indications of its participation in the initial stages of the nervous system development. ${ }^{23,25}$ It has recently been suggested that $\mathrm{BChE}$ could act in an enzymatic reservoir, taking part under certain conditions in a regulatory mechanism of AChE levels in cholinergic synapses. ${ }^{27}$ On the other hand, the physiological function of $\mathrm{AChE}$ is well understood. It acts mainly at the cholinergic receptors located in the central and peripheral nervous systems, performing an important role during the process of transmission of nerve impulses: the catalytic destruction of $\mathrm{ACh}$, which works as cationic neurotransmitter. ${ }^{23,28}$ The role of AChE can be summarized as follows: $\mathrm{ACh}$ is released from the presynaptic nerve in response to an action potential, and diffuses across the synapse, binding itself to the $\mathrm{ACh}$ receptor (which controls the entrance of $\mathrm{K}^{+}$ions into the postsynaptic nerve or the muscular cell, among other functions). After this binding, there occur several events that result in the beginning of the action potential in the postsynaptic cell. In this moment, $\mathrm{AChE}$ quickly hydrolyses $\mathrm{ACh}$, finishing the $\mathrm{ACh}$ receptormediated ion gating and interrupting the transmission of the nerve impulse. ${ }^{28}$ Cholinergic receptors can be classified as nicotinic or muscarinic. Nicotinic receptors are found in autonomic ganglia (ganglionic synapses) and neuromuscular junctions, and are activated by nicotine, while muscarinic receptors, which are located on the parasympathetic effector organs and prejunctionally to neuromuscular junctions, are mainly activated by muscarine. ${ }^{4}$ 
ACh-mediated neurotransmission is a vital process for survival: its abrupt interruption is lethal, and its gradual reduction is associated to progressive deterioration of the cognitive and neuromuscular functions, as in the case of Alzheimer disease, for instance. However, AChE cannot be considered as just an enzyme of the cholinergic nervous system: it appears to be involved in other biological processes, such as neuritogenesis, cell adhesion and differentiation, and amyloid fiber assembly, among others. ${ }^{29}$ Studies are being conducted to confirm or reject these hypotheses of non-classical roles for AChE, and how this knowledge could be employed to develop new therapeutic strategies for neurological diseases..$^{29-31}$ Recent findings indicate that $\mathrm{ACh}$ is not only involved in the correct functioning of the central and peripheral nervous systems: it is a ubiquitous molecule which takes part in the regulation of several other processes, such as cell growth, locomotion and apoptosis, to name just a few. ${ }^{32}$

\subsection{Catalytic mechanism of AChE}

The catalytic mechanism of AChE is based on the formation of a tetrahedral acyl-enzyme intermediate, and involves stages of nucleophilic additions and acid-base reactions. In the decade of 1970, a minimal kinetical model was proposed by Rosenberry, which assumes that an induced-fit conformational adjustment of AChE occurs after substrate binding, but before chemical catalysis. ${ }^{28,33}$ This minimal kinetic model is represented on Figure 1.

The scheme represented in Figure 1 was the first to be proposed for AChE hydrolysis, and is basically a classical Michaelis-Menten model. However, the catalytic action of $\mathrm{AChE}$ and $\mathrm{BChE}$ can be described by this simple model only for neutral substrates, or for low concentrations of positively charged substrates; in other cases, more complex models should be employed. ${ }^{26}$ One of these models takes into consideration the possibilities of substrate-activation and substrate-inhibition. ${ }^{34}$ Other models have been proposed to explain the differences in the kinetics of hydrolysis among $\mathrm{AChE}$ of several species. As an example, we can cite the model for action of Drosophila melanogaster AChE proposed by Stojan et al., ${ }^{35}$ which considers the modulation of the enzyme catalytic action due to binding of the substrate to a secondary active site.

$\mathrm{AChE}$ has an outstanding catalytic performance: its turnover number exceeds $10^{4} \mathrm{~s}^{-1}$, and acetylcholine diffusion to the enzyme active site is the rate-limiting stage of the process. It is noteworthy that $\mathrm{AChE}$ is not a selective enzyme, as it catalyzes not only ACh hydrolysis, but also several reactions involving arylic esters, anilides, thioesters, amides, selenoesters, and other acylic and $\mathrm{N}$-demethylated compounds analogous to AChE. ${ }^{28}$

\subsection{AChE structure}

AChE is a polymorphic enzyme, constituted by globular catalytic subunits, each one with a mass of 70-80 kDa. These subunits group themselves in oligomeric structures that can be divided in two classes: the globular forms and the asymmetric (or elongated) forms. The globular forms are composed of monomers, dimers or tetramers; in the last two cases, the monomeric units are linked by disulfide bridges, and each one possesses its own active site. The asymmetric forms are constituted by three structural subdomains: the catalytic subunits (which are globular), the collagenous subunit and the noncollagenous subunit. The collagenous subunit is a proteic structure, rich in glycine, hydroxyproline and hydroxylysine, and generally contains a triple helix. This subunit ends in a noncollagenous subunit, which are disulfide-linked to the catalytic subunits. The polymorphic forms of AChE are found in several organs of various species. Despite their structural differences, the catalytic subunits activities in the globular and asymmetrical forms are similar. ${ }^{28,36}$

Torpedo californica AChE (TcAChE) was the first to have its primary structure determined. ${ }^{22} \mathrm{~A}$ few years later, the primary structure of human AChE (HuAChE) was discovered. ${ }^{37} \mathrm{TcAChE}$ was also the first one to have

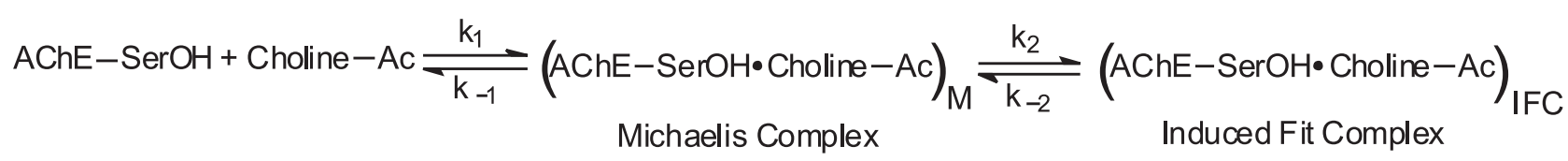

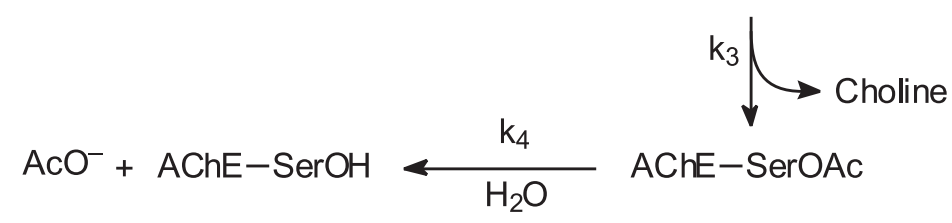

Figure 1. Minimal kinetic mechanism of AChE catalysis. 
its three-dimensional crystalline structure determined by $\mathrm{X}$-ray diffraction..$^{38}$ Generally, the AChE's of different species are well conserved, and $\mathrm{TcAChE}$ has more than $60 \%$ of identity when compared to mammals AChE's ${ }^{23}$ (it is interesting to note that the identity between, the $\mathrm{AChE}$ and the BChE of a same species, or of genetically proximal species, varies from 50 to $52 \%$ ). The high identity among the sequences of TcAChE and mammals AChE's, including the human, renders the tertiary structures of these enzymes very similar. This fact, associated to the good resolutions of TcAChE structures available in the Brookhaven Protein Data Bank (PDB), has made TcAChE the preferred enzyme in theoretical and experimental studies of acetylcholinesterases. The three-dimensional structure of TcAChE (PDB ID 1EA5) is represented in Figure 2.

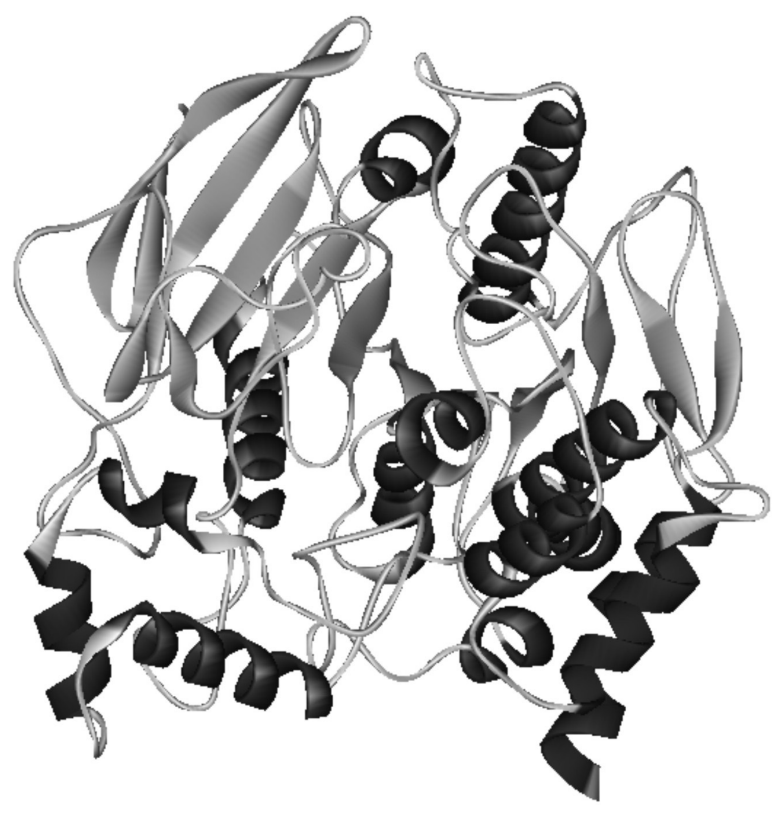

Figure 2. Tridimensional structure of Torpedo californica AChE (PDB ID 1EA5).

TcAChE is naturally found in a homodimeric form. The monomer has 537 residues and is ellipsoid-shaped, with approximate dimensions of $45 \AA \times 60 \AA \times 65 \AA$. It is constituted by a 12 -stranded central $\beta$-sheet surrounded by $14 \alpha$-helices. The first and the last pairs of strands each form a $\beta$-hairpin loop, which are loosely hydrogen-bonded to the eight remaining strands. ${ }^{38} \mathrm{TcAChE}$ is homologous to several lipases and esterases, resulting in similar threedimensional structures for all of them. ${ }^{39}$ However, this folding pattern (a $\beta$-sheet surrounded by $\alpha$-helices) is also found in hydrolases that bear no similarity to TcAChE or among themselves. This fold, first identified in the 1990 's, is designated $\alpha / \beta$ hydrolase. ${ }^{40}$ It is believed that, in TcAChE, this folding is kept by four salt bridges $.^{39} \mathrm{In}-$ depth descriptions of structural details and disulfide-linkage patterns, as well as comparisons with structures of other enzymes, can be found elsewhere..$^{24,28,38,39}$

\subsection{AChE active site}

Essentially, the AChE active site is composed by a catalytic triad, formed by Ser-200, Glu-327 and His-440 in TcAChE22,36,38,41,42 and by Ser-203, Glu-334 and His-447 in HuAChE.42 This triad is similar to the ones present in other serine hydrolases and serine proteases, where there is an aspartate instead of the glutamate found in AChE,38,43 as well as an opposite "handedness", as described by Sussman et al. ${ }^{38}$ In TcAChE, the catalytic triad is located at the bottom of a deep and narrow gorge, known as active site gorge, which has about $20 \AA$ of depth and penetrates approximately halfway in the enzyme, with a widening near its bottom. The $\mathrm{O}$-atom of the Ser-200 residue is located $4 \AA$ above the bottom of the gorge, ${ }^{38}$ whose wall is aligned by 14 highly conserved aromatic residues that interact with quaternary ammonium ions, and also by a few acidic residues. ${ }^{38,44,45}$ Moreover, the distribution of charged residues in AChE results in a permanent dipole moment that is aligned with the axis of the active site gorge; this characteristic facilitates the attraction of a positively charged substrate, guiding it through the gorge. ${ }^{46}$ The direct interaction of the substrate with the negatively charged residues situated in the gorge is shielded by the side chains of the aromatic residues. ${ }^{47}$ This electrostatic steering caused by the huge dipole moment, associated with the quadrupole and other multipole moments of the enzyme, contributes to its high catalytic efficiency. ${ }^{38,44,47-49}$ The narrowest part of the gorge is smaller than the cross section of the $\mathrm{ACh}$, indicating the need of conformational changes of at least part of the gorge to allow the penetration of the substrate. ${ }^{50}$ The fast release of the products of the enzymatic catalysis remains unexplained, although some studies have proposed the possibility of conformational changes that would open alternative "back doors", through which at least some water molecules would exit, while the choline would exit by the principal opening. ${ }^{47,49,50}$ The acetate formed in by the hydrolysis of ACh would leave the active site mainly through the principal opening, with a small fraction leaving through a back door formed during the enzymatic reaction. ${ }^{51,52}$

The catalytic triad is not the only component of the active site, although it is undoubtedly the principal part. Quinn divided the active site in three subsites, ${ }^{28}$ and others domains have been added to his classification since then. According to Quinn and as shown in Figure 3, the active site of AChE can 
be divided in: ( $i$ ) an esteratic subsite, where the serine and the histidine of the catalytic triad are located, which binds to the acyl group of ACh; (ii) an anionic subsite, constituted by negative charges that interact with the quaternary ammonium group of ACh; (iii) a hydrophobic region, contiguous or close to the esteratic and anionic subsites, which is important for the binding of arylic substrates.

Quinn also considered the existence of a fourth domain in $\mathrm{AChE}$, which binds to cationic substrates. This domain is located near the ridge of the gorge, more than $20 \AA$ away from the active site, and is denominated peripheral anionic site. The binding of ligands to this peripheral site frequently causes conformational changes in the active site. These four domains act in a concerted way, resulting in the complex reaction dynamics that characterize $\mathrm{AChE} .^{28,53}$

As mentioned before, the enzymatic hydrolysis of ACh involves nucleophilic additions and acid-base reactions, and is based mainly on the action of the triad catalytic residues. The proposed mechanism most consistent with available experimental data consists of two nucleophilic attacks and two proton-transfers, with a covalent acylenzyme intermediate. In TcAChE, His-440 abstracts a

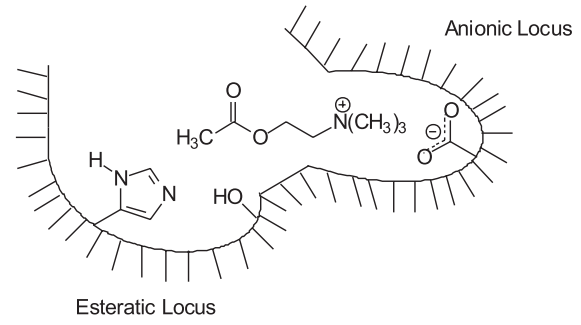

Figure 3. Scheme of the AChE active site.

proton from Ser-200, forming a nucleophile Ser- $\mathrm{O}^{-}$that attacks the ACh molecule, generating a tetrahedral adduct as intermediate. The protonated His-440 is stabilized by Glu-327 and, to a lesser extent, by Glu-199. The stabilization of existing charges in the transition state results in the exceptional catalytic power of AChE. ${ }^{43,45,51,54-}$ 57 This mechanism is represented in Figure 4. His-440 has a high mobility during the catalytic action of $\mathrm{AChE},{ }^{58}$ and its exact positioning is fundamental for achieving optimal catalytic activity. This positioning is obtained by steric hindrance of Phe- 288 and by $\pi$-stacking with Phe-331..$^{53,59,60}$
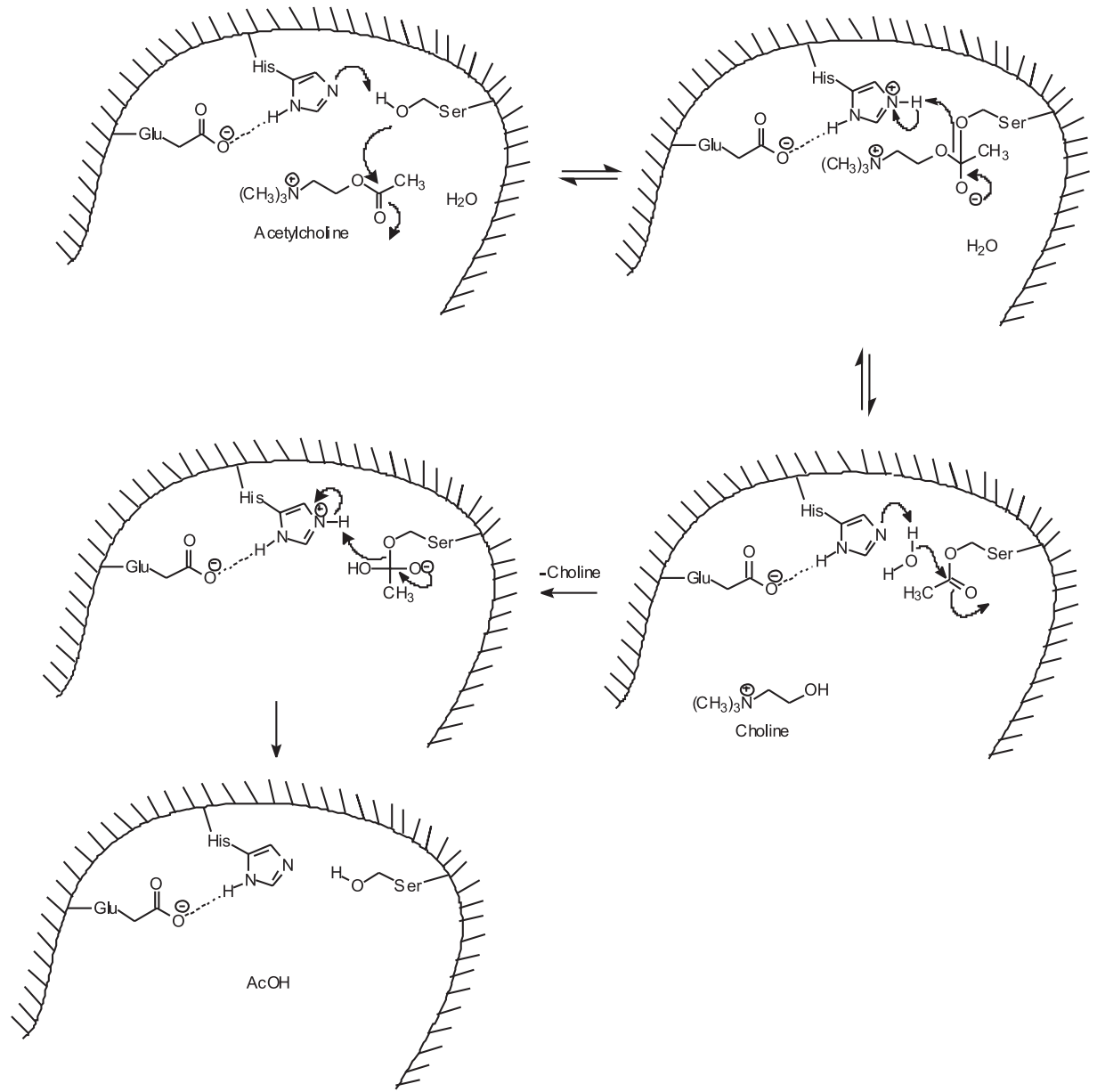

Figure 4. Mechanism of ACh hydrolysis by AChE. 
The residues Trp-84, Glu-199 and Phe-330 are the main components of the anionic subsite (also known as choline binding site), strongly interacting with the quaternary ammonium group of ACh. ${ }^{45,61-63}$ Particularly, Trp-84 is very close $(3.7 \AA)$ to the ammonium group, and both Trp-84 and Phe-330 interact with this group by cation- $\pi$ interactions ${ }^{64}$ Although used for long time, the expression "anionic subsite" is not precise, since it contains, at most, one formal negative charge; the cation- $\pi$ interactions are responsible for the binding of choline to the active site, and not any eventual ionic interaction. ${ }^{38,61,65}$

Phe-288 and Phe-290 (which correspond to Phe-295 and Phe-297 in HuAChE and in other mammals) have a great importance in the active site: they delimit a space where the acyl group of the substrate accommodates itself, designated as acyl pocket. These residues are responsible for the higher specificity of $\mathrm{AChE}$ when compared to $\mathrm{BChE}$ : the big volume of the Phe sidechains limits the available space in the acyl pocket to an acetyl or propanoyl group. In $\mathrm{BChE}$, these Phe are replaced by smaller residues (Leu, Ile or Val), resulting in a more spacious acyl pocket, capable of accommodating larger groups such as butanoyl or benzoyl. ${ }^{25,66}$ Mutagenesis experiments showed that mouse AChE with the mutations Phe295Leu and Phe297Ile loses its specificity and reduces its maximum catalytic rate $\left(\mathrm{k}_{\mathrm{cat}}\right)$, which leads to the conclusion that these residues are important for substrate stabilization at the optimal catalysis position. ${ }^{25}$ Moreover, mutations Phe297Ile and Phe297Val change the kinetic profile of AChE from one of substrate-inhibition to another of substrate-activation analogous to that of BChE. ${ }^{25,67}$ The TcAChE acyl pocket is complemented by residues Trp-233 and Phe-331, which are involved in the mentioned maintenance of the right orientation of His-440 for catalysis..$^{59,60}$

An important structural characteristic found in the active site of AChE is an arrangement of hydrogen-bond donors that stabilize the acyl-enzyme intermediate, accommodating the negative charge of the carbonyl group (which is in the form $\mathrm{C}^{-} \mathrm{O}^{-}$in the acylation and deacylation intermediates). This arrangement forms a cavity known as oxyanion hole, where the carbonyl group accommodates itself. This hole is formed by residues Gly-118, Gly-119 and Ala-201 in TcAChE, and by Gly-121, Gly-122 and Ala-204 in HuAChE. The NH groups of these residues' backbones hydrogen-bond to the carbonyl. ${ }^{38,45,54,55,65}$ The residues in the oxyanion hole and in the acyl pocket take part in the stabilization of acylation and deacylation intermediates, accommodating them without the need of major conformational changes. ${ }^{68}$

The peripheral anionic site is located near the ridge of the active site gorge and, although is not directly involved in AChE catalytic activity, comprises several superposed sites for the binding of allosteric inhibitors and activators. The exact structure and functional role of the peripheral anionic site are still unknown, but it was discovered that some allosteric inhibitors act by a combination of steric hindrance (blocking the way of ligands entering and leaving the active site gorge) and allosteric modifications in the conformation and efficiency of the catalytic triad. ${ }^{69}$ It is also known that Tyr-70, Tyr-121 and Trp-279 are certainly part of the peripheral anionic site, and that this domain binds to cationic and aromatic ligands which are too large to penetrate the active site gorge, or to long bisquaternary ligands which can extend themselves from the ridge to the bottom of this gorge. ${ }^{24,61,63,70}$

As can be seen in Figure 4, water molecules play an important role in AChE catalysis. A study of several crystalline structures of $\mathrm{TcAChE}$ showed that most water molecules are in well-conserved positions, and that some of these molecules move after AChE binds to the substrate, while others remain approximately in the same position. ${ }^{50} \mathrm{It}$ is noteworthy that when $\mathrm{AChE}$ catalyzes the hydrolysis of substances less reactive than $\mathrm{ACh}$, there occur changes in the mechanism of reaction, the action of the catalytic triad being replaced by a basic catalysis involving Glu-199. ${ }^{62}$

Other structural aspects of AChE and BChE which are not discussed in this review can be found elsewhere. ${ }^{70}$ $\mathrm{AChE}$ is the main target of the neurotoxic CWAs, which will be discussed next.

\section{Organophosphorus Compounds as Neuro- toxic Chemical Warfare Agents (CWAs)}

\subsection{Organophosphorus compounds}

Neurotoxic chemical warfare agents are essentially organophosphorus compounds (OPCs) that inhibit AChE activity, resulting in several deleterious effects in the victim (including death). OPCs and carbamates are the AChE inhibitors most used nowadays. Many substances of these two classes compounds are used as insecticides, but only OPCs are employed as CWAs. ${ }^{71,72}$ Accidental intoxications and suicide attempts with insecticides constitute a serious health problem, mainly in Third World countries: World Health Organization estimates that there occurs annually three millions of poisoning cases due to pesticides, with more than 220.000 deaths caused by them around the world. ${ }^{73,74}$ Some OPCs are also used as flame retardants in electrical devices and as antiparasites in veterinary medicine..$^{72}$ Although less lethal than chemical weapons, organophosphorus pesticides can lead to similar deleterious effects when used in greater amounts or higher 
concentrations. ${ }^{75}$ In fact, the World Health Organization reports about three million cases per year of intoxication with organophosphorus pesticides, causing about 220.000 deaths, in the world. ${ }^{73,74}$ These intoxications usually result from wrong manipulation of pesticides and suicidal attempts. ${ }^{73,76,77}$

Phosphorus is an extremely versatile element, located below nitrogen in Group V of the Periodic Table. Its general application in many reactions in organic chemistry results from its electronic structure $\left(1 s^{2} 2 s^{2} 2 p^{6} 3 s^{2} 3 p^{3}\right)$. Consequently, phosphorus can adopt several stable oxidation states, including $+3,+5$ and +6 , and can be naturally found bonded to organic and inorganic ligands. The usefulness of phosphorous reagents in organic synthesis stems from the phosphorus ability to progress from the lowest to highest coordination number (and, occasionally, in the reverse direction). Key factors of phosphorous compounds include the high nucleophilicity of trivalent phosphorous reagents towards electrophiles, its strong and readily formed bonds with oxygen, sulphur, nitrogen and halogens, and the capacity of phosphorus to stabilize adjacent anions. ${ }^{78}$

Organophosphorus compounds are organic substances which contain a phosphoryl $(\mathrm{P}=\mathrm{O})$ or a thiophosphoryl $(\mathrm{P}=\mathrm{S})$ bond. ${ }^{72}$ They are essentially esters, amides or thiolic derivatives of phosphoric, phosphonic or phosphinic acids, with different arrangements of attached oxygen, carbon, nitrogen or sulfur atoms..$^{72,79}$ The classification of OPCs is quite complex, due to the extraordinary variety of side chains that can be attached to the phosphorus atom. Because<smiles></smiles><smiles></smiles><smiles>[R]OP([R])([R])=S</smiles>

Phosphonothioates<smiles>[R]OP([R5])([R])=S</smiles>

Phosphorodithioates<smiles>[R]OP([R5])([R])=O</smiles>

Phosphorothioates S-substituted<smiles>[R5]P([R5])([R5])=O</smiles>

Phosphorotrithioates

of this, no universal classification system for OPCs has been widely accepted to date. According to Gupta, ${ }^{72}$ there are at least 13 types of OPCs, whose structures are shown in Figure 5. OPCs usually have two alkyl substituents and an additional substituent known as "leaving group", since it is more susceptible to hydrolysis or substitution by nucleophiles than the alkyl groups. OPCs that are derivatives from phosphoric and phosphonic acids generally have anticholinesterase activity, in opposition to OPCs derived from phosphinic acid. ${ }^{72}$

The toxic effects of OPCs in humans and insects were discovered in 1932 and 1937, respectively. In 1940, it was proven that $\mathrm{AChE}$ is the main target of OPCs in mammals, and a few years later it was found out that the same is true for insects. ${ }^{80}$ OPCs employed as CWAs are much more potent than the ones used as insecticides, which usually present selective toxicity towards insects, relatively to mammals, because of structural differences in AChE receptors, as well as in other binding subsites. ${ }^{80,81}$ It is noteworthy that only toxicity to insects does not qualify an OPC (or any other substance) as insecticide: it should have other properties, mainly efficacy in low concentrations, low toxicity to mammals, low phytotoxicity and economic viability. ${ }^{82}$ The use of OPCs as insecticides began in the 1940's, and has received a great impulse between 1960 and 1980, when they gradually replaced the organochloride insecticides (which are less toxic, but much more persistent in the environment). In 1999, OPCs represented about $40 \%$ of the global market of pesticides. ${ }^{82}$<smiles>[R]P([R])([R])=O</smiles>

Phosphinates<smiles>[R]OP([R5])([R5])=O</smiles>

Phosphonothioates S-substituted<smiles>[R]N([R])P([R])([R])=O</smiles>

Phosphoroamidates<smiles>[R]OP([R])([R])=S</smiles><smiles>[R]P([R5])([R5])=O</smiles>

Phosphorodithioates<smiles>[R]N([R])P([R])([R])=S</smiles>

Phosphoroamidethioates<smiles>[R]N([R])P([R5])([R5])=S</smiles>

Phosphoroamidethioates<smiles>[R]OP([R])(=O)F</smiles>

Phosphorofluoridates<smiles>[R]P([R])(=O)F</smiles>

Phosphonofluoridates

Figure 5. Types of OPCs, according to Gupta. ${ }^{72}$ 
Before reaching AChE, OPCs may suffer several metabolic biotransformations. Most OPCs (except phosphates and phosphonates) show no or little anticholinesterase activity in their nonmetabolized form. ${ }^{83}$ The biotransformation of non-toxic OPCs to active metabolites occurs through many different reactions, being the most representative of them the oxidative desulfuration of the thiophosphate group, converting the thiophosphoryl bond to a phosphoryl. In this way, phosphorothioates and phosphorodithioates, which are usually weak AChE inhibitors (due to the low electronegativity of sulfur when compared to oxygen), are converted to their oxidized forms, which are extremely toxic anticholinesterase compounds. ${ }^{83-85}$ Other important metabolic reactions are those that result in the detoxification of OPCs. These processes involve the breaking one of the phosphorus bonds, forming a negatively charged molecule, ${ }^{83}$ or the increase in water solubility of the OPC, making its excretion easier and reducing its half-life in the organism. ${ }^{85}$

\subsection{Mechanism of action of OPCs}

OPCs used as CWAs and as insecticides act by inhibiting AChE, preventing hydrolysis of ACh. This causes an accumulation of ACh in all cholinergic receptors, resulting in overstimulation of the structures enervated by these cholinergic fibers. The mechanism of the reaction involves a nucleophilic attack of the serine in the AChE catalytic triad (Ser-200 in TcAChE, Ser-203 in HuAChE) to the phosphorus atom in the OPC. Unlike acetylated AChE, which quickly converts itself in acetic acid and regenerated AChE, the phosphylated enzyme ('phosphylation' denotes both 'phosphorylation' and phosphonylation') is stable and, depending on the groups attached to the phosphorus atom, becomes irreversibly inhibited. The lack of activity of the inhibited enzyme occurs because the serine of the catalytic triad, when phosphylated, can no longer hydrolyze ACh. ${ }^{4,36,75,84,86,87}$ A scheme of AChE inhibition by OPCs is shown in Figure 6. Computational studies of AChE phosphonylation by the nerve agent sarin indicate that the reaction actually involves a two-step addition-elimination mechanism, rather than a concerted one; the addition would be the rate-determining step. ${ }^{88,89} \mathrm{OPCs}$ are also able to inhibit BChE action by an analogous mechanism, but the effects of this inhibition in the organism are unknown, since the physiological function of this enzyme is not fully understood yet. ${ }^{86}$ Moreover, OPCs covalently bond to other serine esterases, such as carboxylesterase, neuropathy target esterase (NTE), trypsin and chymotrypsin. ${ }^{79}$

The reaction of OPCs with cholinesterases initially involves the formation of the OPC-enzyme Michaelis complex, followed by the phosphylation of the enzyme and its subsequent inactivation, with replacement of the OPC leaving group by the alcoholic oxygen of the catalytic triad serine. The phosphylated enzyme is stable; nonetheless, the phosphyl-enzyme complex eventually suffers one of different possible secondary processes. The first possibility is the spontaneous reactivation: hydrolysis of the phosphylenzyme complex regenerates the cholinesterase, with elimination of the OPC (although this process can be
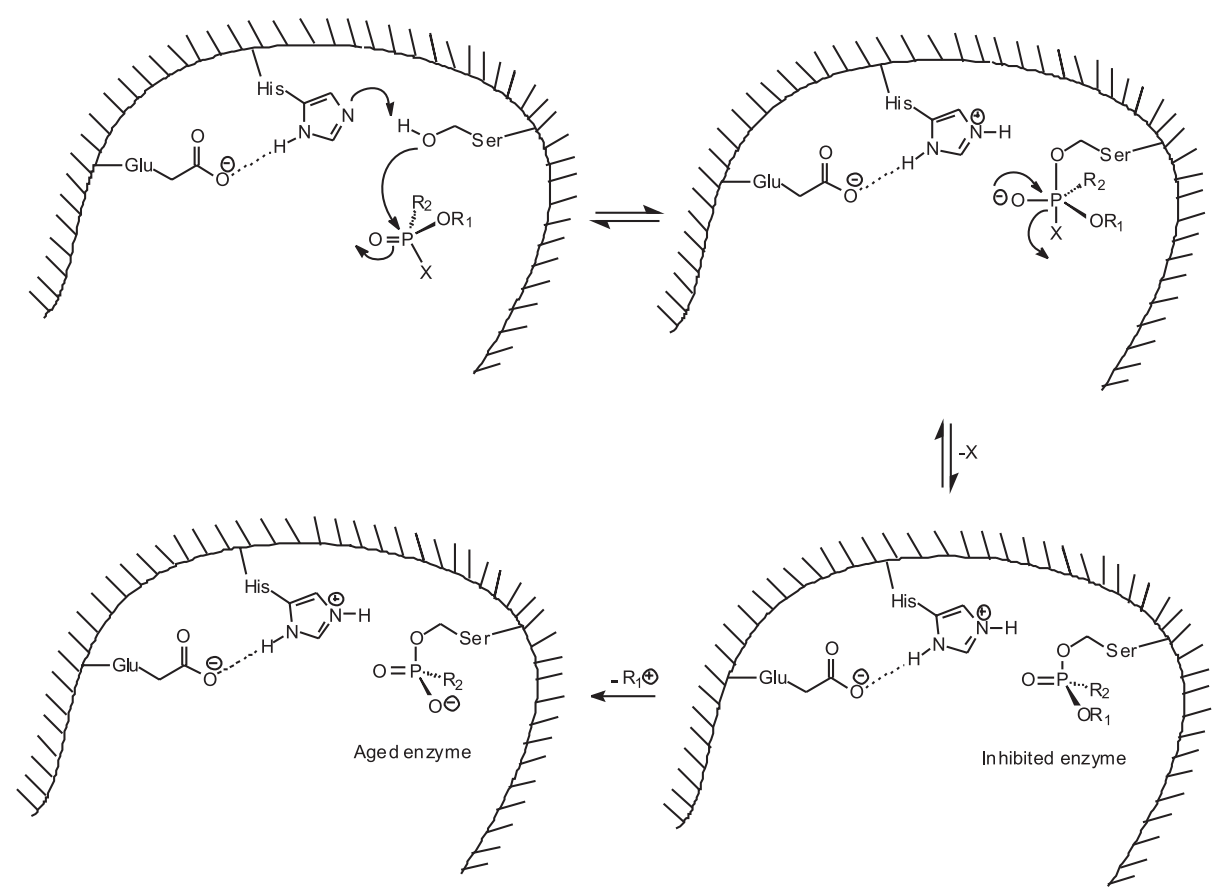

Figure 6. Scheme of AChE inhibition by OPCs and aging ( $\mathrm{X}=$ leaving group). 
very slow to be clinically significant). As will be seen, this reactivation can be accelerated by the use of adequate nucleophiles. ${ }^{1,2,4,79}$

Another possibility is the breaking of the $\mathrm{PO}-\mathrm{C}$ bond of the phosphylated enzyme, with the subsequent loss of an alkylic carbenium (Figure 6). After this reaction, known as aging, the phosphylated enzyme can no longer be efficiently reactivated spontaneously or by the action of nucleophiles, becoming irreversibly inhibited., ${ }^{1,2}$ The mechanism of aging by monodealkylation of a dialkylphosphyl-enzyme is considered classical; non-classical mechanisms have been described. In the case of the nerve agent tabun, aging occurs by breaking of a $\mathrm{P}-\mathrm{N}$ bond, instead of a PO-C bond, with elimination of a dimethylamine group, ${ }^{90,91}$ however, the possibility of occurring a classical aging for tabun has been recently proven. ${ }^{92}$ Some OPCs can age by different mechanisms. For instance, the insecticide mipafox $\left[\mathrm{O}=\mathrm{P}(\mathrm{F})\left(\mathrm{NHCH}\left(\mathrm{CH}_{3}\right)_{2}\right)_{2}\right]$ ages by deprotonation of one of its phosphoroamide groups in the complex with human NTE, ${ }^{3}$ by loss of two isopropyl groups in the complex with $\mathrm{HuAChE}^{94}$ (as represented in Figure 7), and by loss of just one isopropyl group in the complex with equine BChE. ${ }^{95}$

The aged phosphylated cholinesterase cannot be reactivated due to several factors. ${ }^{96,97}$ Firstly, the aged complex possesses a negative charge in the active site, making the attack of a negatively charged nucleophile more difficult. Besides, various non-covalent forces stabilize the aged complex: interactions among the OPC and the oxyanion hole, the acyl pocket and the histidine at the active site either stabilize the aged complex, either limit the dephosphylation by blocking the access of water or other nucleophiles to the phosphorus atom. ${ }^{98-102}$ Another factor that may contribute to the resistance of aged enzymes for reactivation is the conformational changes that they suffer after aging, making the OPC less exposed to nucleophilic attacks. ${ }^{96}$ Finally, at least in the case of the nerve agent soman, it has been proposed the existence of a "push-pull" electrostatic mechanism, involving residues Glu-199, His-440, Trp-84 and the oxyanion hole in TcAChE, which would stabilize the carbenium formed during aging and favor a methyl migration that would transform a secondary carbenium in a tertiary one. ${ }^{97,99,103,104}$

Spontaneous reactivation rates of phosphylated cholinesterases are determined by the structure of the phosphyl-enzyme. Except for the nerve agents, spontaneous reactivation occurs at clinically significant rates with the majority of the OPCs, but it is always slower than the deacetylation that happens in the hydrolysis of the natural substrate: Deacetylation of AChE occurs in microseconds, but dephosphylation in hours to days. Generally, the smaller the alkyl groups of the OPC, the faster will be spontaneous reactivation. ${ }^{4}$ Aging rates also depend on the structure of the phosphyl-enzyme complex.

Nucleophilic substitutions of OPCs, all of which have a tetra-coordinated phosphorus atom, pose two questions: what is the position of attack of the nucleophile, and which leaving group is effectively replaced? For reactions with strong nucleophiles, it is considered that the nucleophile approaches perpendicularly to the trigonal face of the phosphorus-centered tetrahedron that is opposed to the leaving group. In this way, a pentavalent trigonal bipyramidal intermediate is formed, where the nucleophile and the leaving group are located on the apical positions (see Figure 6). ${ }^{105-108}$ In OPCs with more than a potential leaving group, the intermediate structure influences which group will be replaced, determining the product stereochemistry. In OPCs, it is common a competition between a alcoxy and a thioalkyl leaving group, the former being more electronegative and the latter being more polarizable, less basic and, therefore, a better leaving group. In the absence of restraining steric

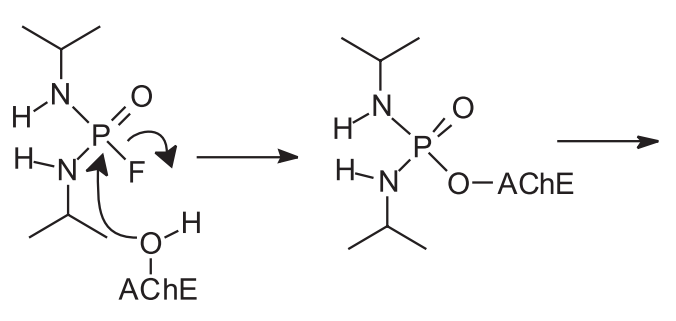

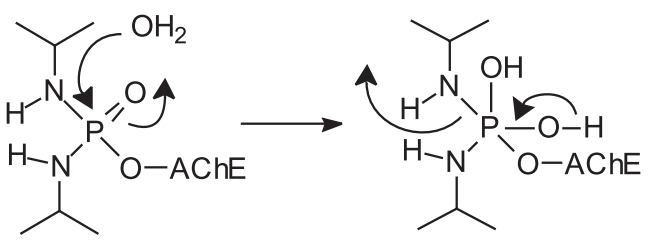
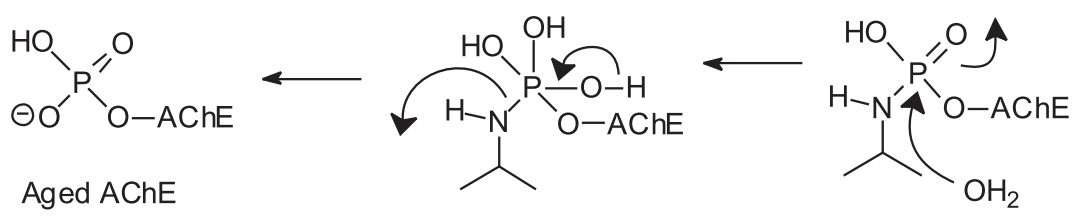

Figure 7. Mechanism of aging of AchE inhibited by mipafox. ${ }^{94}$ 
effects, the most electronegative substituents tend to occupy the apical positions in trigonal bipyramidal structures, ${ }^{107,109,110}$ which would make them the preferable leaving groups. However, the possibility of occurrence of pseudorotations around the phosphorus atom and the possible existence of steric hindrances may result in a less electronegative group occupying an apical position in the intermediate, so becoming the preferable leaving group. ${ }^{106,110,111}$ So, breaking of a $\mathrm{P}-\mathrm{O}$ or a $\mathrm{P}-\mathrm{S}$ bond will be the result of a competition between the apicophilicity of the alcoxy group, kinetically favored, and the better stability as leaving group of the thioalkyl group, thermodynamically favored. ${ }^{106,108,112}$

OPCs cause several deleterious effects in the organism, since ACh accumulation results in an excessive stimulation of nicotinic and muscarinic receptors in both central and peripheral nervous systems. The muscarinic symptoms are the result of an increase of activity of the parasympathetic system and include miosis, salivation, abdominal pain and bradycardia, while the nicotinic symptoms, which affect the autonomic ganglia, are usually tachycardia and hypertension. Effects at both, muscarinic and nicotinic receptors can occur at different organs, like the hart or the central nervous system (CNS). At the CNS the symptoms are usually headache, muscle tremors, giddiness, convulsions and respiratory arrest, being the latter the responsible for most fatalities caused by OPCs. ${ }^{3,4,113}$ The signs and symptoms of intoxication by these agents (cholinergic syndrome) just appear when more than $50 \%$ of AChE is inhibited, and death occurs after inhibition of $90 \%$ of the enzyme. ${ }^{71}$ Interestingly, the symptoms caused by different nerve agents are similar, with the differences being caused by the variation of inactivation or ageing rates, as well as differences in absorption, distribution and metabolism. ${ }^{4}$ Long-term effects, observable from weeks to months, have been registered, and are due to constant exposition to low doses of OPCs, or to late effects of acute expositions. ${ }^{3,4,114}$

It should be noted that $\mathrm{AChE}$ inhibition does not constitute the only toxic effect of OPCs, since these<smiles>CCOP(=O)(C#N)N(C)CC</smiles>

Tabun<smiles>CCOP(C)(=O)SCCNC(C)C</smiles>

VX<smiles>CC(C)OP(C)(=O)F</smiles>

Sarin

Cyclosarin

compounds also inhibit other enzymes. Besides, very high concentrations of cholinesterases inhibitors (many times the lethal dose) can cause direct effects on cholinergic receptors, for instance by blocking the ionic channels. Finally, OPCs can affect other neurotransmission pathways, such as the dopaminergic and the noradrenergic ones, although these perturbations seem to be secondary when compared to effects on cholinergic systems. Despite the relevance of these alternative mechanisms for the clinical effects of OPCs not being completely understood yet, ${ }^{3,4} \mathrm{a}$ recent study has mathematically modeled the lethal effects in vivo of several highly toxic OPCs used as nerve agents, concluding that their primary mechanism of action is really AChE inhibition: less than $10 \%$ of their toxicity can be attributed to alternative mechanisms. ${ }^{115}$

\subsection{OPCs as chemical warfare agents}

The so-called neurotoxic chemical warfare agents, also known as nerve gases or nerve agents, are OPCs which have a very high toxicity to mammals, particularly percutaneously or by inhalation. Their toxicity is much higher than that of OPCs used as insecticides. ${ }^{3,4}$ Nerve gases are usually phosphonofluoridates and S-substituted phosphonothioates, while most OPCs used as insecticides are phosphonothioates with the $\mathrm{P}=\mathrm{S}$ bond. The main neurotoxic CWAs are known by their military designations attributed by the North Atlantic Organization Treaty (NATO): GA (also denominated tabun; O-ethylN,N-dimethyl-phosphoramidecyanidate), GB (sarin; O-isopropyl-methyl-phosphonofluoridate), GD (soman; O-pinacolyl-methyl-phosphonofluoridate) and VX (O-ethyl S-[2-(diisopropylamine)ethyl]-methyl-phosphonothioate). These agents are considered nerve gases because they have favorable characteristics for military use, and their structures are represented on Figure 8. There are registrations of an old nerve agent, designated as GF (cyclosarin; O-cyclohexylmethyl-phosphonofluoridate), whose manufacture is
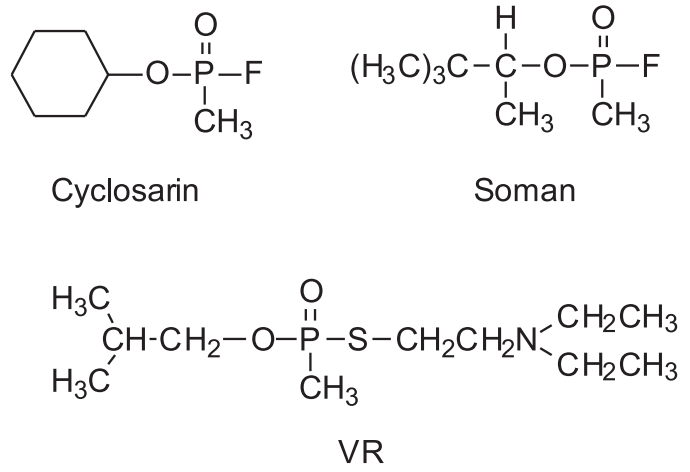

Figure 8. Structures of the main neurotoxic chemical warfare agents. 
similar to that of sarin. This neurotoxic agent would have been discarded by U.S.A. as being of no military interest (for reasons still unknown), and was fabricated by Iraq during the Gulf War. ${ }^{3}$ VR (or Russian VX; O-isobutyl S-[2(diethylamine)ethyl]-methylphosphonothioate) is a VXanalogous developed by the Soviet Union. Structures of GF and VR are also represented in Figure 8. Other less relevant (and less studied) nerve agents are GE (O-isopropyl-methylphosphonofluoridate), CVX (O-n-butyl S-[2-(diethylamine) ethyl]-methylphosphonothioate, also known as Chinese VX), VE (O-ethyl S-[2-(diethylamine)ethyl]-ethylphosphonothioate), VG (O,O-diethyl S-[2-(diethylamine) ethyl]-ethyl-phosphorothioate) and VM (O-ethyl S-[2(diethylamine)ethyl]-methyl-phosphonothioate). ${ }^{4}$

Anticholinesterase compounds have been used as weapons in Africa since the XIX century, at least, and the first AChE inhibitor OPC to be developed was probably tetraethylpyrophosphate, synthesized by Wurtz in $1854 .^{3}$ However, the history of modern nerve agents begins in the 1930's, when the German conglomerate Farbenindustrie initiated a program of syntheses of several compounds, in an attempt to develop new insecticides. In this program, tabun and sarin were synthesized by Schrader in 1936 and 1937, respectively. The high toxicity of these compounds to mammals limited their use as insecticides, but attracted the attention of the German Ministry of Defense, which anticipated their potential as weapons and created a pilot plant for their industrial production in 1942. In 1944, Richard Kuhn synthesized soman, but there was no time to weaponize it before the end of World War II. VX was synthesized in the 1950's in the United Kingdom, being weaponized by U.S.A., and cyclosarin was first synthesized in 1949 , by a process analogous to the synthesis of sarin..$^{3,4}$
Although known as 'nerve gases', neurotoxic OPCs are actually colorless liquids at room temperature: their boiling point varies from $158{ }^{\circ} \mathrm{C}$ (sarin) to $298{ }^{\circ} \mathrm{C}$ (VX). G-series compounds are relatively volatile and offer more risk when inhalated; VX is very little volatile, and it may be necessary weeks before its complete dissipation. In this way, VX offers low risk of being inhalated (unless at high temperatures), and an elevated risk of being absorbed through the skin. ${ }^{3}$ Some physical, chemical and toxicological properties of nerve agents are summarized on Table 2 . It is believed that toxicity differences among them are partially due to differentiated AChE inhibitions in different parts of the brain. ${ }^{116} \mathrm{VR}$ is not listed on Table 2, but recent studies have shown few differences between the in vitro toxicities of VX and VR, although the former is a bit more toxic. ${ }^{117}$

All nerve agents present optical isomery: tabun, sarin, cyclosarin, VX and VR have one chiral phosphorus atom each, while soman has an additional stereocenter at a carbon atom of the pinacolyl group. These stereoisomers react with $\mathrm{AChE}$ at different rates and possess distinct toxicological properties, ${ }^{113}$ so toxicological data in Table 2 should be considered as regarding non-specified mixtures of stereoisomers of each nerve agent. These differences result from the stereochemistry of the active site of AChE, which favors the accommodation of one enantiomer at the active site in detriment to the binding of another one. It is believed that the phenylalanine residues in the acyl pocket (mainly Phe-290 in TcAChE) are the major agents of this selectivity, due to the steric constraints imposed by them. ${ }^{66,118}$ However, molecular modeling ${ }^{97}$ and mutagenesis studies ${ }^{63,119}$ have shown that the oxyanion hole, the anionic subsite and the peripheral anionic site also play an important role in stabilization of the phosphyl-AChE complex and in stereoselectivity.

Table 2. Physical, chemical and toxicological properties of the principal nerve agents

\begin{tabular}{|c|c|c|c|c|}
\hline Property & Tabun (GA) & Sarin (GB) & Soman (GD) & vX \\
\hline Molecular weight / (Da) & 162.3 & 140.1 & 182.2 & 267.4 \\
\hline Boiling point / $\left({ }^{\circ} \mathrm{C}\right)$ & 230 & 158 & 198 & 298 \\
\hline Melting point / $\left({ }^{\circ} \mathrm{C}\right)$ & -49 & -56 & -80 & -20 \\
\hline Vapor pressure / mm Hg & $0.037\left(20^{\circ} \mathrm{C}\right)$ & $2.1\left(20^{\circ} \mathrm{C}\right)$ & $0.40\left(25^{\circ} \mathrm{C}\right)$ & $0.0007\left(20^{\circ} \mathrm{C}\right)$ \\
\hline Vapor Density (relative to air) & 5.6 & 4.9 & 6.3 & 9.2 \\
\hline Liquid Density / (g per $\mathrm{mL}$ at $\left.25^{\circ} \mathrm{C}\right)$ & 1.08 & 1.10 & 1.02 & 1.01 \\
\hline Volatility / (mg per $\mathrm{m}^{3}$ a $\left.25^{\circ} \mathrm{C}\right)$ & 610 & 22000 & 3900 & 10.5 \\
\hline Solubility in water & $9.8 \mathrm{~g}$ per $100 \mathrm{~g}\left(25^{\circ} \mathrm{C}\right)$ & miscible & $2.1 \mathrm{~g}$ per $100 \mathrm{~g}\left(20^{\circ} \mathrm{C}\right)$ & Miscible \\
\hline Persistency on soil & $1-1.5$ day (half-life) & $2-24 \mathrm{~h}\left(5\right.$ to $\left.20^{\circ} \mathrm{C}\right)$ & relatively persistent & 2-6 days \\
\hline $\mathrm{LCt}_{50}$ in humans $/\left(\mathrm{mg} \min\right.$ per $\left.\mathrm{m}^{3}\right)$ & 400 & 100 & 50 & 10 \\
\hline $\mathrm{LD}_{50}$ in humans / (mg per $70 \mathrm{~kg}$ in human) & 1000 (percutaneous) & 1700 (percutaneous) & 350 (percutaneous) & 6-10 (percutaneous) \\
\hline
\end{tabular}

Sources: references 3 and 4 . 
For nerve agents, the stereoisomer with the absolute configuration shown in Figure 9 is usually the most active AChE inhibitor, since the R'O group is greater than the $\mathrm{R}$ group. ${ }^{113}$ This configuration corresponds to the S-isomers of sarin and VX, and to S-configuration around the phosphorus atom $\left(\mathrm{P}_{\mathrm{S}}\right)$ for soman. ${ }^{63,97,118}$ Table 3 shows the effect of the stereochemistry of nerve agents on their anticholinesterase activity and acute lethality, which is not very expressive. ${ }^{97}$ In the particular case of soman, there is low selectivity related to the chiral carbon atom. In fact, the $\mathrm{P}_{S} \mathrm{C}_{\mathrm{S}}$ isomer is a bit more toxic than the $P_{S} C_{R}$, and there is practically no difference between their aging rates, ${ }^{120}$ probably because the same carbenium is formed in both cases.

In soman, isomers $\mathrm{P}(-)$ have $\mathrm{S}$-configuration on the phosphorus atom, and isomers $\mathrm{C}(-)$ have $\mathrm{S}$-configuration on the chiral carbon atom. ${ }^{97}$ Recently, it has been proved that (+)-tabun and (-)-tabun have R- and S-configuration, respectively. ${ }^{121}$

Since AChE inhibition is irreversible after aging, there is a great interest on the study of the kinetics of this process. Aging rates vary among the several OPCs: for tabun, the half-life for the aging of the phosphyl-AChE is about 19 hours; for sarin, 3 hours; for cyclosarin, 7 hours; for VX, 36.5 hours; and for soman, only 2 minutes. ${ }^{75,79}$ The extraordinarily fast aging rate of soman constitutes a great challenge for the treatment of victims of this agent, since it demands a nearly immediate administration of the currently used antidotes, limiting their efficacy. It is believed that the rapid aging of soman is due to the formation of a tertiary carbenium (which later rearranges itself in neutral compounds) by a methyl migration in the secondary pinacolyl carbenium aided by a 'push-pull' mechanism, as shown in Figure 10.97,99,103,104

Table 4 compiles data of rate constants for inhibition of HuAChE by racemic mixtures of several nerve agents,<smiles>[R]P([R])([R])=O</smiles>

Figure 9. Absolute configuration of the most active nerve agent stereoisomers for $\mathrm{AChE}$ inhibition.

Table 3. Effect of the stereochemistry of nerve agents on their anticholinesterase activity and acute lethality

\begin{tabular}{|c|c|c|}
\hline $\begin{array}{l}\text { Nerve agent } \\
\text { stereoisomer }\end{array}$ & $\begin{array}{l}\text { Rate constant for AChE } \\
\text { inhibition / } \\
\left(\mathrm{mol} \mathrm{L}^{-1} \mathrm{~min}^{-1}\right) \text { at } 25^{\circ} \mathrm{C}\end{array}$ & $\begin{array}{c}\mathrm{LD}_{50} \text { (in mice) / } \\
\quad(\mu \mathrm{g} \text { per } \mathrm{kg})\end{array}$ \\
\hline $\mathrm{C}(+) \mathrm{P}(-)$-soman & $2.8 \times 10^{8}$ & 99 (sc) \\
\hline $\mathrm{C}(-) \mathrm{P}(-)$-soman & $1.8 \times 10^{8}$ & $38(\mathrm{sc})$ \\
\hline $\mathrm{C}(+) \mathrm{P}(+)$-soman & $<5 \times 10^{3}$ & $>5000(\mathrm{sc})$ \\
\hline $\mathrm{C}(-) \mathrm{P}(+)$-soman & $<5 \times 10^{3}$ & $>2000$ (sc) \\
\hline $\mathrm{C}( \pm) \mathrm{P}( \pm)$-soman & not available & $156(\mathrm{sc})$ \\
\hline$(-)$-sarin & $1.4 \times 10^{7}$ & 41 (iv) \\
\hline$(+)$-sarin & $<3 \times 10^{3}$ & not available \\
\hline$( \pm)$-sarin & not available & 83 (iv) \\
\hline (-)-tabun & $2.3 \times 10^{6}$ & 119 (iv) \\
\hline (+)-tabun & $3.7 \times 10^{5}$ & 837 (iv) \\
\hline$( \pm)$-tabun & not available & 208 (iv) \\
\hline$(-)-V X$ & $4 \times 10^{8}$ & 12.6 (iv) \\
\hline$(+)-\mathrm{VX}$ & $2 \times 10^{6}$ & 165 (iv) \\
\hline$( \pm)-V X$ & not available 1 & 20.1 (iv) \\
\hline
\end{tabular}

Source: reference 113 .

and also presents rate constants for aging and spontaneous reactivation of the phosphylated enzyme in each case.

A phenomenon not observed in other nerve agents occurs with tabun. When this compounds forms a complex with mouse AChE, still without aging, a movement of the imidazolic ring of His-447 dislocates Tyr-337 and Phe-338, thus reducing the diameter of the active site gorge and

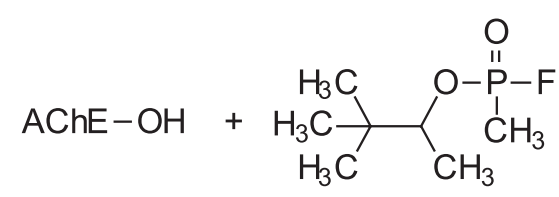<smiles>CCCOP(C)(=O)OC(C)C(C)(C)C</smiles>

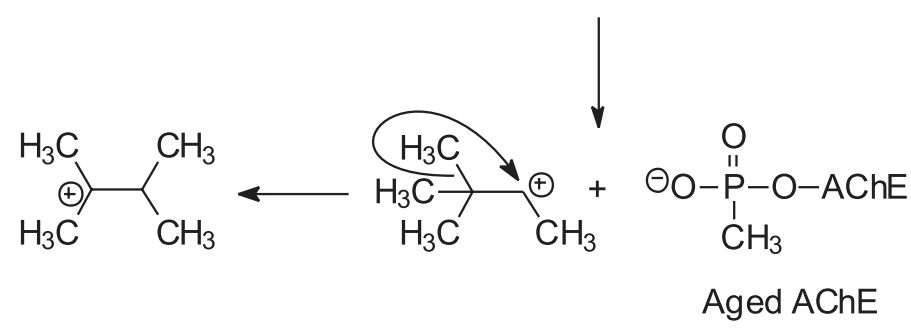

Figure 10. Mechanism for the aging of the soman-AChE complex. 
Table 4. Rate constants for HuAChE inhibition by nerve agents $\left(\mathrm{k}_{\mathrm{i}}\right)$ and for aging $\left(\mathrm{k}_{\mathrm{a}}\right)$ and spontaneous reactivation $\left(\mathrm{k}_{\mathrm{r}}\right)$ of inhibited $\mathrm{HuAChE}$

\begin{tabular}{lccc}
\hline Nerve agent & $\mathrm{k}_{\mathrm{i}} /\left(\mathrm{mol} \mathrm{L}^{-1} \mathrm{~min}^{-1}\right)$ & $\mathrm{k}_{\mathrm{a}} /\left(\mathrm{h}^{-1}\right)$ & $\mathrm{k}_{\mathrm{r}} /\left(\mathrm{h}^{-1}\right)$ \\
\hline Tabun & $7.4 \pm 0.2 \times 10^{6}$ & $0.036 \pm 0.001$ & N.D. \\
Sarin & $2.1 \pm 0.1 \times 10^{7}$ & 0.228 & N.D. \\
Soman & $9.2 \pm 0.4 \times 10^{7}$ & 6.6 & N.D. \\
Cyclosarin & $4.9 \pm 0.0006 \times 10^{8}$ & $0.099 \pm 0.003$ & N.D. \\
VX & $1.2 \pm 0.002 \times 10^{8}$ & $0.019 \pm 0.001$ & $0.021 \pm 0.001$ \\
VR & $4.4 \pm 0.006 \times 10^{8}$ & $0.005 \pm 0.001$ & $0.039 \pm 0.002$ \\
\hline
\end{tabular}

Each entry in the table indicates mean value \pm standard deviation of 2-5 experiments. N.D.: no spontaneous reactivation of AChE activity during the observation period. Source: reference 75.

hampering the access of the antidote. ${ }^{121}$ This conformational change is reversible, so that the cited residues reverse to the original positions in the apoenzyme and in the aged tabun-AChE complex. It is believed that this phenomenon, denominated conformational aging, renders reactivation of tabun-inhibited AChE quite difficult, even before aging of the complex. ${ }^{122}$

Another important problem by the use of CWAs is the need of safe and effective cleaning of the contaminated areas and victims skin. Due to their volatility, G-agents have a short biological half-life, while VX and other V-agents are more persistent in the environment. There are several processes for chemical or enzymatic decontamination for these purposes. The discussion of this important subject is beyond the scope of this review, but it may be found elsewhere. ${ }^{123-126}$

\subsection{Treatment and antidotes for nerve agents}

Intoxication with different nerve agents leads to similar symptoms and effects, caused mainly by accumulation of acetylcholine.

Despite their high lethality, most nerve gases have a relatively short period of action, being quickly degraded or dispersed to non-lethal concentrations. ${ }^{13}$ So, just after an attack with one of these agents, there are significant possibilities for the emergency services to treat the majority of the exposed victims, providing emergency care and, when possible, transporting them to better-equipped facilities. The principles of medical treatment of OPCs victims are the same applied to victims of intoxications by any other toxic substance, that is, termination of exposure to the toxic agent; establishment or maintenance of appropriate ventilation; administration of adequate antidotes, if available; and, finally, correction of cardiac abnormalities. All care must be taken by rescue personnel in order to avoid their own contamination during the treatment and transportation.
This is accomplished by the use of appropriate suits and individual protection equipments and the complete decontamination of victims. ${ }^{3}$ In battle situations, removal of victims of nerve agents to decontamination locals may be a very hard task to accomplish. In these cases, fast administration of antidotes becomes the main priority. With this problem in mind, autoinjector syringes were developed, allowing the administration of the antidotes by the victim itself (or by a colleague) at the first signs of contamination by nerve agents. ${ }^{127,128}$

When exposure to nerve agents is expected, prophylactic measures may be taken. One of them involves pretreatment with carbamates, such as pyridostigmine or physostigmine. Carbamates are reversible inhibitors of AChE and, once bonded to the enzyme active site, prevents its irreversible inhibition by OPCs, being spontaneously hydrolyzed later. ${ }^{129-131}$ However, their continuous use causes some collateral effects (mainly gastrointestinal). ${ }^{129}$ The use of patches for transdermal drug administration ${ }^{132-133}$ can help to circumvent or mitigate these effects. Another prophylactic alternative consists on the use of compounds which sequester of degrade the nerve agent before it gets to its target. These compounds are denominated scavengers, and are classified as stoichiometric or catalytic. The stoichiometric scavengers are enzymes which bind stoichiometrically and irreversibly to the OPC (such as the cholinesterases themselves), while the catalytic scavengers hydrolyze the molecules of OPCs (such as OPC hydrolases and anhydrases). ${ }^{134,135}$ Several enzymes are being evaluated for use as scavengers, such as human serum BChE, recombinant human BChE expressed in the milk of transgenic goats, genetic variants of AChE and human paraoxonase. ${ }^{134-138}$ Oximes can be employed for pretreatment, improving the post-treatment by atropine and other oximes ${ }^{132,139}$ (see below), but some questions should be addressed for their use, such as timing, duration and achievement of adequate concentrations after administration. ${ }^{132,133}$

The chemotherapy employed for the treatment of intoxication with OPCs includes the use of three types of drugs: ${ }^{1,3,13,128}(i)$ an anticholinergic substance, to antagonize the effects of $\mathrm{ACh}$ accumulation in the cholinergic receptors; (ii) a central nervous system (CNS) depressor, which acts as an anticonvulsive; and (iii) an oxime to reactivate inhibited $\mathrm{AChE}$.

Atropine, whose structure is shown in Figure 11, is the most used anticholinergic. It competes with ACh for the muscarinic receptors, blocking the effects of the excess of ACh. Atropine is effective in the treatment for all OPCs, being adopted as standard antidote since the end of the decade of 1940 until the present, in spite of the continuous research for new antidotes. However, atropine is unable 


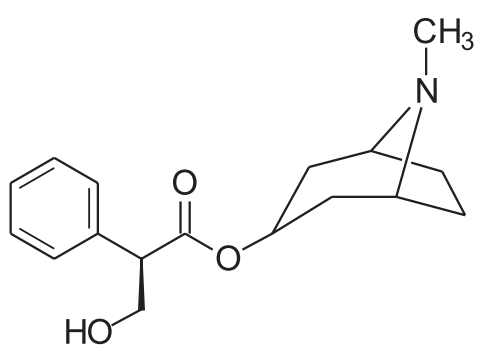<smiles>CN1C(=O)CN=C(c2ccccc2)c2cc(Cl)ccc21</smiles>

Figure 11. Structures of atropine and diazepam.

to counterbalance the action of OPCs in the nicotinic receptors. It should be noted that atropine does not prevent AChE inhibition by OPCs; it just antagonizes the effects of ACh accumulation.

CNS depressors are used to mitigate the convulsions and the muscle spasms commonly associated to acute OPC intoxications. Diazepam, also represented in Figure 11, is the most used compound of this class, but many other analogues can be employed.

Several oximes are employed for reactivation of AChE inhibited by OPCs, provided that the phosphylated enzyme is not aged yet. They are especially useful in the treatment of OPCs nicotinic effects. The diverse oximes differ among themselves in the optimal dose for reactivation, in toxicity and in effectiveness. However, all of them have three great deficiencies: (i) the utilized oximes are generally quaternary ammonium ions and, as hydrophilic compounds, have many difficulties to cross the blood-brain barrier: their concentrations in the brain are only 1 to $10 \%$ of their plasma levels. ${ }^{140-142}$ As a consequence, they can reactivate only a small fraction of the inhibited AChE in the CNS; (ii) oximes do not reactivate aged phosphyl-enzymes; and (iii) unlike atropine, oximes are not effective against all OPCs, having different activities for each one of them.

Oximes that reactivate $\mathrm{AChE}$ are usually mono or bispyridinic ones. One of the most used of them is pralidoxime, or 2-PAM (2-pyridinium aldoxime), employed in the form of chloride (in USA) or methanesulfonate (in UK). Other European countries utilize other oximes, such as trimedoxime (TMB-4) or obidoxime (or toxogonin)., ${ }^{1,3,143}$ The structures of these compounds are shown in Figure 12.
A deficiency of the cited oximes is their low efficacy against soman intoxications. On the other hand, the socalled Hagedorn oximes are much more effective against this nerve agent. The structures of the main Hagedorn oximes (HI-6, HLö-7, HGG-12 e HGG-42) are represented on Figure 13. In general, it can be said that 2-PAM is efficient in vitro against sarin and VX, but not against soman, tabun and cyclosarin; obidoxime is effective against sarin, VX and tabun, but not against soman and cyclosarin; and HI-6 is highly efficient against sarin, soman and VX, but not against tabun. The most recent HLö-7 seems to be able to reactivate AChE inhibited by sarin, soman, cyclosarin, tabun and VX, and may constitute the first step towards a truly universal AChE reactivator. ${ }^{1,75,143,144}$ The relative toxicity of these oximes to humans is HI- $6<$ HLö-7 < 2-PAM < obidoxime < trimedoxime. ${ }^{127}$ Despite the activity of those compounds, there are several problems for the reactivation of AChE in vivo. For example, it should be reminded that the fast aging of the AChE phosphylated by soman limits the use of any oxime as a reactivator. ${ }^{143}$ Also, HI-6 and HLö-7 decompose in aqueous solution, and must be stored as lyophilized powder. ${ }^{145}$ To solve this last problem, a recent study has evaluated the possibility of using HI-6 dimethanesulfate, which is more stable and water soluble than the hydrochloride. The obtained results in that investigation have been encouraging. ${ }^{146}$

Nucleophilic reactivation of phosphylated AChE by an oxime occurs through the mechanism described in Figure 14. Usually, it is considered that the oxime reacts in the deprotonated form (oximate) in nucleophilic reactivation, as represented in Figure 14. ${ }^{147}$ However, there are indications<smiles>C[n+]1ccccc1/C=N/O</smiles>

Pralidoxime (2-PAM)<smiles></smiles>

Figure 12. Structures of 2-PAM, trimedoxime and obidoxime. 
<smiles>NC(=O)c1cc[n+](COC[n+]2ccccc2/C=N/O)cc1</smiles>

HI-6<smiles>O=C(c1ccccc1)c1ccc[n+](COC[n+]2ccccc2/C=N/O)c1</smiles>

HGG-12<smiles>NC(=O)c1cc[n+](COC[n+]2ccc(/C=N/O)cc2/C=N/O)cc1</smiles><smiles>O=C(c1ccc[n+](COC[n+]2ccccc2/C=N/O)c1)C1CCCCC1</smiles>

HGG-42

Figure 13. Structures of the main Hagedorn oximes.

pointing to the possibility that the reaction occurs with the neutral oxime, instead of the oximate; ${ }^{148}$ additional studies are needed to elucidate this question. ${ }^{149}$ The nucleophilic attack of the oximate (or oxime) to the phosphorus atom is facilitated by the polarization of the phosphoryl bond, which is enhanced by the oxyanion hole. In general, the phosphylenzymes derived from nerve agents with $\mathrm{S}_{\mathrm{p}}$ configuration (which are more toxic) are more prone to reactivation; this indicates that polarization of the phosphoryl bond is necessary for an efficient reactivation by nucleophiles. ${ }^{118,150}$ Ideally, the oximate and the enzyme (the leaving group in the reactivation) would occupy the axial positions in the trigonal bipyramidal intermediate; however, steric constraints in the active site gorge prevent the optimal attack of the oximate. Because of this, reactivations by oximes are much slower than phosphylation reactions. ${ }^{118,150}$

The possibility of AChE reinhibition by the phosphylated oxime may pose a serious clinical problem. ${ }^{151,152}$ Accordingly, an efficient reactivator should have an unstable phosphylated form. This factor reduces the efficacy of the 4-pyridinium aldoximes (such as 4-PAM, TMB-4 and obidoxime), whose phosphylated forms decompose slower than those of 2-pyridinium aldoximes). ${ }^{152,153}$ Nevertheless, human serum capacity to decompose phosphylated oximes attenuates this negative effect. ${ }^{154}$ Therefore, the efficiency of an oxime as an antidote for intoxication with neurotoxic OPCs is function of the nucleophilicity of the oximate (or the oxime itself) and the exclusion from the active site and decomposition rate of the phosphylated oxime. ${ }^{143}$

Structural models for the mechanism of action and the differences in activity among oximes have been proposed. ${ }^{122,147,150,155,156}$ It is known that an adequate orientation of the phosphoryl bond inside the active site is necessary for both the enzyme efficient inhibition and its reactivation; however, the orientation of the oximes in the active site and their angles for attacking the phosphylated serine are different. ${ }^{150}$ Many new oximes have been synthesized, and their capacities of AChE reactivation evaluated. ${ }^{157-170}$ Figure 15 shows the structure of some of those new promising bis-pyridinium oximes. For example 1,7-heptylene-bis- $N, N^{\prime}$-syn-2pyridiniumaldoxime, which is 200 times more active than 2-PAM and could lead to the development of compounds able to reactivate aged phosphorylated HuAChE. ${ }^{158}$ Other examples of new promising bis-pyridinium oximes are K027 [1-(4-hydroxyiminomethylpyridinium)-

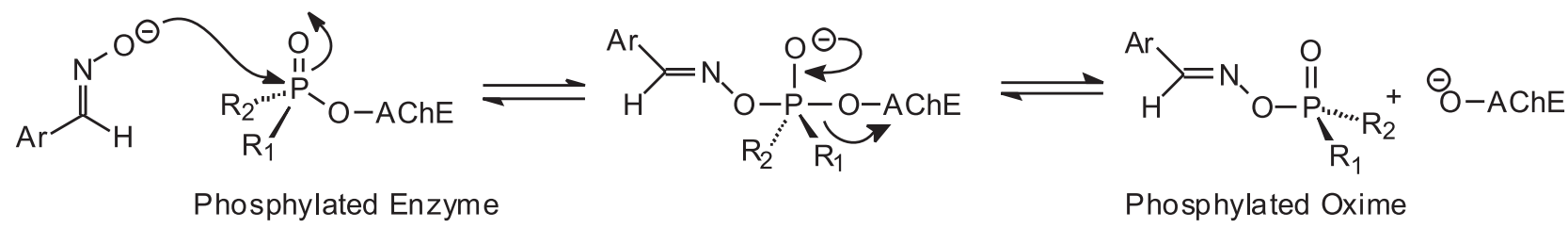

Figure 14. Reactivation of phosphylated AChE by oximes. 
3-(4-carbamoylpyridinium) propane dibromide], K048 [1-(4-hydroxyiminomethylpyridinium)-4-(4carbamoylpyridinium) butane dibromide], which display low toxicity against different types of human cells but have a very good capacity to reactivate $\mathrm{HuAChE}$ inhibited with tabun, ${ }^{161,165}$ and similar oximes with an unsaturated liker, like K203 ((E)-1-(4-carbamoylpyridinium)4-(4-hydroxyiminomethylpyridinium)-but-2-ene dibromide). ${ }^{166,167}$ There are evidences that at least some oximes (mainly HI-6 and HLö-7) also act on the treatment of intoxications through direct pharmacological effects, which are not related to AChE reactivation. However, the mechanism of these effects is not well understood yet, but there are some hypotheses. ${ }^{127,171}$ For example, it has been suggested that HI-6 may interfere with GABA-ergic inhibition, a process that is related to regulation of respiration. ${ }^{171}$ Oximes can bind to the active site of AChE or to the peripheral anionic site, acting as a reversible inhibitors and preventing the enzyme interaction with OPCs. Although this phenomenon has been well documented in in vitro studies, it has not been evaluated yet in terms of experimental toxicology. ${ }^{127}$

Several factors can lead an oxime to be ineffective in the treatment of OPCs intoxications. For instance, it is possible that steric or electronic effects result in low reactivation rates, which happens particularly with phosphoroamidates, such as tabun. Also, due to the employed low doses of oximes, it is possible that the rate of AChE inhibition by an OPC is higher than the reactivation rate by the oxime. The oxime optimal concentration might not be kept during the necessary period, when treatment is interrupted too early. Finally, as already cited, AChE re-inhibition by the phosphylated oximes reduces the antidote efficacy. The treatment regimen with oximes must be rigorously followed in order to maximize the antidote effects, although there are still many doubts about the adequate regimen under certain conditions. ${ }^{172}$ Nowadays, it is still discussed even the need of administration of oximes to victims of OPCs intoxication. ${ }^{173-175}$

Studies have shown that, to be an effective AChE reactivator, a compound should possess some structural properties: it should have a quaternary nitrogen atom, which guides the molecule to the active site by interacting with the anionic subsite. ${ }^{145}$ Also, the length and the stiffness of the chain linking the pyridinium rings should be adequate for the action against the target OPC. Finally, the antidote molecule should possess one or more oxime groups properly positioned. ${ }^{176}$ Nonetheless, the reason for the necessity of this oxime group, instead of another nucleophilic one, is not well understood yet. A proposed explanation considers the alpha effect presented by oximes and oximates. ${ }^{177,178}$ Our research group is conducting further investigations on this point, trying to better understand the need of an oxime as an antidote.

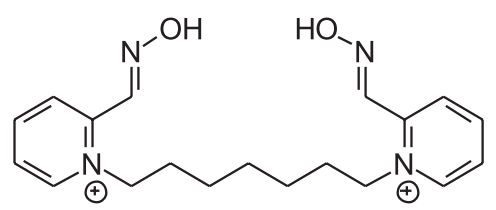

1,7-heptylene-bis- $N, N^{\prime}$-syn-2-pyridiniumal doxime<smiles>NC(=O)c1cc[n+](CCC[n+]2ccc(/C=N/O)cc2)cc1</smiles><smiles>NC(=O)c1cc[n+](CCCC[n+]2ccc(/C=N/O)cc2)cc1</smiles><smiles></smiles><smiles>NC(=O)c1cc[n+](C/C=C/C[n+]2ccc(/C=N/O)cc2)cc1</smiles>

Figure 15. Structures of 1,7-Heptylene-bis- $N, N^{\prime}$-syn-2-pyridiniumaldoxime, K027, K033, K048 and K203. 


\section{Conclusions}

Despite the widespread adherence to the Chemical Weapons Convention, chemical warfare agents still constitute a threat, due to the possibility of their use by Non-Signatory States or by terrorist groups. Among these weapons, organophosphorus neurotoxic agents are the most dangerous. No universal antidote against these compounds is known to date, and the possibility of aging demands a quick-acting AChE reactivator (especially for soman).

The development of antidotes for intoxication with neurotoxic OPCs is important, not only because their potential use as chemical warfare defense agents, but also for the treatment of intoxication with organophosphorus pesticides, which are very intensively used in agriculture.

Continuous research on new oximes for $\mathrm{AChE}$ reactivation is being conducted all around the world. However, the incomplete knowledge about the interaction between the oxime and the nerve agent inside the enzyme active does not allow a rational approach for new drugs design; most of the research of new oximes is on empirical basis. It is expected that the application of molecular modeling techniques may eventually shed some light on this subject.

\section{Acknowledgments}

We gratefully acknowledge the Brazilian Ministry of Defense and CAPES (Pro-defesa), CNPq and IMBEB ${ }_{2}$ for financial support.

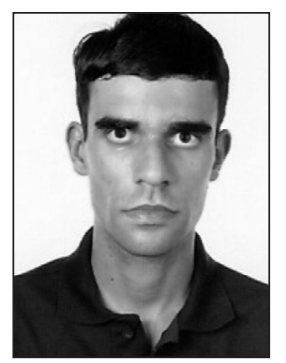

Reinaldo Teixeira Delfino graduated in Chemical Engineering at Military Institute of Engineering (IME), Rio de Janeiro, Brazil (1995). From that Institute, he also received his M.Sc. (2002) and his Ph.D. (2008) in Chemistry, both of them under the orientation of Prof. José D. Figueroa-Villar. He is Captain of the Brazilian Army, and currently Professor of Calculus at IME. His main interests are focused in molecular modeling applied to defense against chemical and biological warfare.

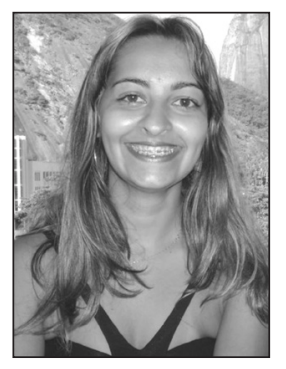

Tatiana S. Ribeiro received her B.Sc. in Chemistry in 2002 and M. Sc. in Organic Synthesis in 2004 from the Institute of Chemistry, Rural Federal University of Rio de Janeiro (UFRRJ), Brazil. Currently, she is a Chemistry Ph. D. student at the Department of Chemistry, Military
Institute of Engineering (IME) under the supervision of Prof. José Daniel Figueroa-Villar, working with the synthesis, biological evaluation and NMR kinetics of antidotes for intoxication with neurotoxic compounds.

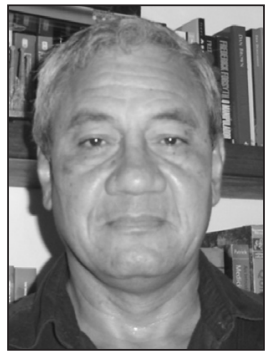

José Daniel Figueroa-Villar obtained his B. Sc. in Chemistry at Universidad de Costa Rica in 1977 and started his M. Sc. in Biochemistry at the same university in 1978. He obtained his Ph. D. in Organic Chemistry at the University of Alberta, Canada, in 1983, under the orientation of William A. Ayer. He worked as pos-doctoral fellow and research associate at the same university until 1985. In 1986 he became Professor of Chemistry at the Military Institute of Engineering in Rio de Janeiro, Brazil where he is working until now. He was founder of the NMR Users Association (AUREMN) in 1987. In 1999 he created the journal Annals of Magnetic Resonance, being its actual Chief Editor. He is the president of AUREMN since 2000. His main area of work is Medicinal Chemistry (NMR, molecular modeling and synthesis) applied to the discovery of chemotherapy for tropical infectious diseases and for defense against chemical and biological warfare agents.

\section{References}

1. Somani, S. M.; Solana, R. P.; DUBE, S. N. In Chemical Warfare Agents; Somani, S. M., ed., Academic Press Inc.: San Diego, 1992, pp. 68-123.

2. Black, R. M.; Harrison, J. M. In The Chemistry of Organophosphorus Compounds, Vol 4, Ter- and Quinquephosphorus Acids and Their Derivatives; Hartley, F. R., ed., John Wiley \& Sons: Chichester, 1996, pp. 781-840.

3. Sidell, F. R. In Medical Aspects of Chemical and Biological Warfare-Textbook of Military Medicine; Sidell, F.R.; Takafuji, E. T.; Franz, D. R., eds.; Office of the Surgeon General, US Army: Washington D.C., 1997, pp. 129-179.

4. Marrs, T. C. In Chemical Warfare Agents- Toxicology and Treatment; Marrs, T. C.; Maynard, R. L.; Sidell, F. R., eds., $2^{\text {nd }}$ ed., John Wiley \& Sons Ltd: West Sussex, 2007, pp. 191-221.

5. Smart, J. K. In Medical Aspects of Chemical and Biological Warfare-Textbook of Military Medicine; Sidell, F. R.; Takafuji, E. T; Franz, D.R., eds., Office of the Surgeon General, US Army: Washington D.C., 1997, pp. 9-86.

6. Ministério do Exército, Estado-Maior do Exército; Manual de Campanha-Operações Químicas, Biológicas e NuclearesDefesa Contra Ataques Químicos, Biológicos e Nucleares, $1^{\text {st }}$ ed., 1987. 
7. Greenfield, R. A.; Brown, B. R.; Hutchins, J. B.; Iandolo, J. J.; Jackson, R.; Slater, L. N.; Bronze, M. S; Am. J. Med. Sci. 2002, $323,326$.

8. Maynard, R. L. In Chemical Warfare Agents-Toxicology and Treatment; Marrs, T. C.; Maynard, R. L; Sidell, F. R., eds., $2^{\text {nd }}$ ed., John Wiley \& Sons Ltd: West Sussex, 2007, pp. 1-20.

9. Toy, R. J. T. In Medical Aspects of Chemical and Biological Warfare - Textbook of Military Medicine; Sidell, F. R.; Takafuji, E. T; Franz, D. R., eds., Office of the Surgeon General, US Army: Washington D.C., 1997, pp. 87-109.

10. Takafuji, E. T.; Kok, A. B. In Medical Aspects of Chemical and Biological Warfare-Textbook of Military Medicine; Sidell, F. R.; Takafuji, E. T; Franz, D. R., eds. Office of the Surgeon General, US Army: Washington D.C., 1997, pp. 111-128.

11. Ballantyne, B.; Bismuth, C.; Hall, A. H. In Chemical Warfare Agents-Toxicology and Treatment; Marrs, T. C.; Maynard, R. L; Sidell, F. R., eds., $2^{\text {nd }}$ ed., John Wiley \& Sons Ltd: West Sussex, 2007, pp. 495-542.

12. OPCW: http://www.opcw.nl/factsandfigures/index. html\#participation, accessed in September 2008.

13. Cannard, K.; J. Neurol. Sci. 2006, 249, 86.

14. UN Report S/16433; United Nations: New York, NY, 1984.

15. UN Report S/117911; United Nations: New York, NY, 1986.

16. MacIlwain, C.; Nature 1993, 363, 3.

17. Nagao, M.; Takatori, T.; Matsuda, Y.; Nakajima, M.; Iwase, H.; Iwadate, K.; Toxicol. Appl. Pharmacol. 1997, 144, 198.

18. Yanagisawa, N.; Morita, H.; J. Neurol. Sci. 2005, 238, S8.

19. Yanagisawa, N.; Morita, H.; Nakajima, T.; J. Neurol. Sci. 2006, 249, 76.

20. Yokoyama, K.; Neurotoxicology 2007, 28, 364.

21. Nozaki, H.; Aikawa, N.; Fujishima, S.; Suzuki, M.; Shinozawa, Y.; Hori, S.; Nogaws, S.; Lancet 1995, 346, 698.

22. Schumacher, M.; Camp, S.; Maulet, Y.; Newton, M.; MacPheeQuigley, K; Taylor, S. S.; Friedmann, T; Taylor, P; Nature 1986, 319, 407.

23. Taylor, P.; J. Biol. Chem. 1991, 266, 4025.

24. Taylor, P.; Radic, Z.; Annu. Rev. Pharmacol. Toxicol. 1994, 34 , 281.

25. Vellom, D. C.; Radic, Z.; Li, Y.; Pickering, N. A.; Camp, S.; Taylor, P; Biochemistry 1993, 32, 12.

26. Masson, P.; Froment, M.-T.; Gillon, E.; Nachon, F.; Lockridge, O.; Schopfer, L. M.; Biochim. Biophys. Acta 2007, 1774, 16.

27. Giacobini, E.; Pharmacol. Res. 2004, 50, 433.

28. Quinn, D. M.; Chem. Rev. 1987, 87, 955.

29. Soreq, H.; Seidman, S.; Nat. Rev. Neurosci. 2001, 2, 294.

30. He, X.-C.; Feng, S.; Wang, Z.-F.; Shi, Y.; Zheng, S.; Xia, Y.; Jiang, H.; Tang, X.-C.; Bai, D.; Bioorg. Med. Chem. 2007, 15, 1394.

31. Greenfield, S. A.; Zimmermann, M.; Bond, C. E.; FEBS J. 2008, 275,604 .

32. Shen, Z.-X.; Med. Hypotheses 2008, 70, 43.
33. Rosenberry, T. L.; Proc. Natl. Acad. Sci. U. S. A. 1975, 72, 3834.

34. Rosenberry, T. L.; Johnson, J. L.; Cusack, B.; Thomas, J. L.; Emani, S.; Venkatasubban, K. S.; Chem.-Biol. Interact. 2005, 157-158, 181.

35. Stojan, J.; Marcel, V.; Estrada-Mondaca, S.; Klaebe, A.; Masson, P.; Fournier, D.; FEBS Lett. 1998, 440, 85.

36. MacPhee-Quigley, K.; Taylor, P; Taylor, S.; J. Biol. Chem. 1985 , 260,12185 .

37. Soreq, H.; Ben-Aziz, R.; Prody, C. A.; Seidman, S.; Gnatt, A.; Neville, L.; Lieman-Hurwitz, J.; Lev-Lehman, E.; Ginzberg, D.; Lapidot-Lifson, Y.; Zakut, H.; Proc. Natl. Acad. Sci. U. S. A. 1990, 87, 9688.

38. Sussman, J. L.; Harel, M.; Frolow, F.; Oefner, C.; Goldman, A.; Toker, L.; Silman, I.; Science 1991, 253, 872.

39. Cygler, M.; Schrag, J. D.; Sussman, J. L.; Harel, M.; Silman, I.; Gentry, M. K.; Doctor, B. P.; Protein Sci. 1993, 2, 366.

40. Ollis, D. L.; Cheah, E.; Cygler, M.; Dijkstra, B.; Frolow, F.; Franken, S. M.; Harel, M.; Remington, S. J.; Silman, I.; Schrag, J. D.; Sussman, J. L.; Verschueren, K. H. G.; Goldman, A.; Protein Eng. 1992, 5, 197.

41. Gibney, G.; Camp, S.; Dionne, M.; MacPhee-Quigley, K; Taylor, P; Proc. Natl. Acad. Sci. U. S. A. 1990, 87, 7546.

42. Shafferman, A.; Kronman, C.; Flashner, Y.; Leitner, M.; Grosfeld, H.; Ordentlich, A.; Gozes, Y.; Cohen, S.; Ariel, N.; Barak, D.; Harel, M.; Silman, I.; Sussman, J. L.; Velan, B.; J. Biol. Chem. 1992, 267, 17640.

43. Dodson, G.; Wlodawer, A.; Trends Biochem. Sci. 1998, 23, 347.

44. Axelsen, P. H.; Harel, M.; Silman, I.; Sussman, J. L.; Protein Sci. 1994, 3, 188.

45. Fuxreiter, M.; Warshel, A.; J. Am. Chem. Soc. 1998, 120, 183.

46. Gonçalves, A. S.; França, T. C. C.; Wilter, A.; Figueroa-Villar, J. D.; J. Braz. Chem. Soc. 2006, 17, 968.

47. Ripoll, D. R.; Faerman, C. H.; Axelsen, P. H.; Silman, I.; Sussman, J. L.; Proc. Natl. Acad. Sci. U. S. A. 1993, 90, 5128.

48. Tan, R. C.; Truong, T. N.; McCammon, J. A.; Sussman, J. L.; Biochemistry 1993, 32, 401.

49. Botti, S. A.; Felder, C. E.; Lifson, S.; Sussman, J. L.; Silman, I.; Biophys. J. 1999, 77, 2430.

50. Koellner, G.; Kryger, G.; Millard, C. B.; Silman, I.; Sussman, J. L.; Steiner, T.; J. Mol. Biol. 2000, 296, 713.

51. Enyedy, I. J.; Kovach, I. M.; Brooks, B. R.; J. Am. Chem. Soc. 1998, 120, 8043.

52. Nachon, F.; Stojan, J.; Fournier, D.; FEBS J. 2008, 275, 2659.

53. Shafferman, A.; Barak, D.; Kaplan, D.; Ordentlich, A.; Kronman, C.; Velan, B.; Chem.-Biol. Interact. 2005, 157-158, 123. 
54. Harel, M.; Quinn, D. M.; Nair, H. K.; Silman, I.; Sussman, J. L.; J. Am. Chem. Soc. 1996, 118, 2340.

55. Zhang, Y.; Kua, J.; McCammon, J. A.; J. Am. Chem. Soc. 2002, 124, 10572.

56. Sant'anna, C. M. R.; Viana, A. S.; Junior, N. M. N.; Bioorg. Chem. 2006, 34, 77.

57. Nemukhin, A. V.; Lushchekina, S. V.; Bochenkova, A. V.; Golubeva, A. A.; Varfolomeev, S. D.; J. Mol. Model. 2008, 14, 409.

58. Millard, C. B.; Koellner, G.; Ordentlich, A.; Shafferman, A.; Silman, I.; Sussman, J. L.; J. Am. Chem. Soc. 1999, 121, 9883.

59. Barak, D.; Kaplan, D.; Ordentlich, A.; Ariel, N.; Velan, B.; Shafferman, A.; Biochemistry 2002, 41, 8245.

60. Kaplan, D.; Barak, D.; Ordentlich, A.; Kronman, C.; Velan, B.; Shafferman, A.; Biochemistry 2004, 43, 3129.

61. Harel, M.; Schalk, I.; Ehret-Sabatier, L.; Bouet, F.; Goeldner, M.; Hirth, C.; Axelsen, P. H.; Silman, I.; Sussman, J. L.; Proc. Natl. Acad. Sci. U. S. A. 1993, 90, 9031.

62. Selwood, T.; Feaster, S. R.; States, M. J.; Pryor, A. N.; Quinn, D. M.; J. Am. Chem. Soc. 1993, 115, 10477.

63. Ordentlich, A.; Barak, D.; Sod-Moriah, G.; Kaplan, D.; Mizhari, D.; Segall, Y.; Kronman, C.; Karton, Y.; Lazar, A.; Marcus, D.; Velan, B.; Shafferman, A.; Biochemistry 2004, 43, 11255.

64. Ma, J. C.; Dougherty, D. A.; Chem. Rev. 1997, 97, 1303.

65. Ordentlich, A.; Barak, D.; Kronman, C.; Ariel, N.; Segall, Y.; Velan, B.; Shafferman, A.; J. Biol. Chem. 1998, 273, 19509.

66. Hosea, N. A.; Berman, H. A.; Taylor, P.; Biochemistry 1995, 34, 11528.

67. Taylor, P.; Radic, Z.; Hosea, N. A.; Camp, S.; Marchot, P.; Berman, H. A.; Toxicol. Lett. 1995, 82/83, 453.

68. Silman, I.; Millard, C. B.; Ordentlich, A.; Greenblatt, H. M.; Harel, M.; Barak, D.; Shafferman, A.; Sussman, J. L.; Chem.Biol. Interact. 1999, 119-120, 43.

69. Bourne, Y.; Taylor, P.; Radic, Z.; Marchot, P.; EMBO J. 2003, $22,1$.

70. Radic, Z.; Taylor, P. In Toxicology of Organophosphate \& Carbamate Compounds; Gupta, R. C., ed.; Elsevier Academic Press: London, 2006, pp. 161-186.

71. Moretto, A. Toxicol. Lett. 1998, 102-103, 509.

72. Gupta, R. C. In Toxicology of Organophosphate \& Carbamate Compounds; Gupta, R. C., ed. , $1^{\text {st }}$ ed., Elsevier Academic Press: London, 2006, pp. 5-24.

73. Carlton, F. B; Simpson, W. M.; Haddad, L. M. In Clinical Management of Poisoning and Drug Overdose; Haddad, L. M.; Shannon, M. W.; Winchester, J. F., eds., $3^{\text {rd }}$ ed., WB Saunders Company: Philadelphia, 1998, pp.836-850.

74. Sogorb, M. A.; Vilanova, E.; Carrera, V.; Toxicol. Lett. 2004, $151,219$.

75. Worek, F.; Thiermann, H.; Szinicz, L.; Eyer, P.; Biochem. Pharmacol. 2004, 68, 2237.
76. Larini, L. In Toxicologia; Larini, L., ed., $2^{\text {nd }}$ ed., Editora Manole Ltda: São Paulo, Brazil, 1993, pp. 136-163.

77. Bardin, P. G.; Arch. Intern. Med. 1994, 154, 1433.

78. Carey, F. A.; Sundberg, R. J.; Advanced Organic Chemistry, Part B: Reactions and Synthesis, $4^{\text {th }}$ ed., Plenum; Organophosphorus Reagents in Organic Synthesis, Cadogan, Academic Press; Organic Chemistry, Clayden, Greeves, Warren and Wothers: Oxford, 2001.

79. Worek, F.; Koller, M.; Thiermann, H.; Szinicz, L.; Toxicology 2005, 214, 182.

80. Casida, J. E.; Quistad, G. B.; Chem.-Biol. Interact. 2005, 157158, 277.

81. Casida, J. E.; Quistad, G. B.; J. Pestic. Sci. 2004, 29, 81.

82. Santos, V. M. R.; Donnici, C. L.; DaCosta, J. B. N.; Caixeiro, J. M. R.; Quím. Nova, 2007, 30, 159.

83. Jokanovic, M.; Toxicology 2001, 166, 139.

84. Kwong, T. C.; Ther. Drug Monit. 2002, 24, 144.

85. Tang, J.; Rose, R. L.; Chambers, J. E. In Toxicology of Organophosphate \& Carbamate Compounds; Gupta, R. C., ed., $1^{\text {st }}$ ed., Elsevier Academic Press: London, 2006, pp. 127-143.

86. Fukuto, T. R.; Environ. Health Perspect. 1990, 87, 245.

87. Majumdar, D.; Roszak, S.; Leszczynski, J.; J. Phys. Chem. B 2006, 110, 13597.

88. Wang, J.; Gu, J.; Leszczynski, J.; J. Phys. Chem. B 2006, $110,7567$.

89. Wang, J.; Gu, J.; Leszczynski, J.; J. Phys Chem. B 2008, 112, 3485 .

90. Barak, D.; Ordentlich, A.; Kaplan, D.; Barak, R.; Mizrahi, D.; Kronman, C.; Segall, Y.; Velan, B.; Shafferman, A.; Biochemistry 2000, 39, 1156.

91. Elhanany, E.; Ordentlich, A.; Dgany, O.; Kaplan, D.; Segall, Y.; Barak, R.; Velan, B.; Shafferman, A.; Chem. Res. Toxicol. 2001, 14, 912.

92. Carletti, E.; Li, H.; Li, B.; Ekström, F.; Nicolet, Y.; Loiodice, M.; Gillon, E.; Froment, M. T.; Lockridge, O.; Schopfer, L. W.; Masson, P.; Nachon, F.; J. Am. Chem. Soc. 2008, 130, 16011.

93. Kropp, T. J.; Glynn, P.; Richardson, R. J.; Biochemistry 2004, 43, 3716 .

94. Kropp, T. J.; Richardson, R. J.; Chem. Res. Toxicol. 2006, 19, 334.

95. Kropp, T. J.; Richardson, R. J.; Chem. Res. Toxicol. 2007, $20,504$.

96. Curtil, C.; Masson, P.; Ann. Pharm. Fr. 1993, 51, 63.

97. Bencsura, A.; Enyedy, I.; Kovach, I. M.; Biochemistry 1995, 34, 8989.

98. Ordentlich, A.; Kronman, C.; Barak, D.; Stein, D.; Ariel, N.; Marcus, D.; Velan, B.; Shafferman, A. FEBS Lett. 1993, 334, 215.

99. Qian, N.; Kovach, I. M.; FEBS Lett. 1993, 336, 263.

100. Segall, Y.; Waysbort, D.; Barak, D.; Ariel, N.; Doctor, B. P.; Grunwald, J.; Ashani, Y.; Biochemistry 1993, 32, 13441.

101. Shafferman, A.; Ordentlich, A.; Barak, D.; Stein, D.; Ariel, N.; Velan, B.; Biochem. J. 1996, 318, 833. 
102. Millard, C. B.; Kryger, G.; Ordentlich, A.; Greenblat, H. M.; Harel, M.; Raves, M. L.; Segall, Y.; Barak, D.; Shafferman, A.; Silman, I.; Sussman, J. L.; Biochemistry 1999, 38, 7032.

103. Viragh, C.; Akhmetshin, R.; Kovach, I. M.; Biochemistry 1997, 36, 8243.

104. Saxena, A.; Viragh, C.; Frazier, D. S.; Kovach, I. M.; Maxwell, D. M.; Lockridge, O.; Doctor, B. P.; Biochemistry 1998, 37, 15086.

105. Westheimer, F. H.; Acc. Chem. Res. 1968, 1, 70.

106. DeBruin, K. E.; Tang, C.-I.; Johnson, D. M.; Wilde, R. L.; J. Am. Chem. Soc. 1989, 111, 5871.

107. Thatcher, G. R. J.; Kluger, R.; Adv. Phys. Org. Chem. 1989, $25,99$.

108. Seckuté, J.; Menke, J. L.; Emnett, R. J.; Patterson, E. V.; Cramer, C. J.; J. Org. Chem. 2005, 70, 8649.

109. Muetterties, E. L.; Mahler, W.; Schmutzler, R.; Inorg. Chem. 1963, 2, 613.

110. Cramer, C. J.; Gustafson, S. M.; J. Am. Chem. Soc. 1993, 115, 9315.

111. Cavell, R. G.; Gibson, J. A.; The, K. I.; Inorg. Chem. 1978, 17,2880

112. Menke, J. L.; Patterson, E. V.; J. Mol. Struct. 2007, 811, 281.

113. Benschop, H. P.; De Jong, L. P. A.; Acc. Chem. Res. 1988 , 21, 368.

114. Rafai, M. A.; Boulaajaj, F. Z.; Bourezgui, M.; Charra, B.; Otmani, H. E.; Benslama, A.; Motaouakkil, S.; Slassi, I.; Neurophysiol. Clin. 2007, 37, 35.

115. Maxwell, D. M.; Brecht, K. M.; Koplovitz, I.; Sweeney, R. E.; Arch. Toxicol. 2006, 80, 756.

116. Bajgar, J.; Hajek, P.; Slizova, D.; Krs, O.; Fusek, J.; Kuca, K.; Jun, D.; Bartosova, L.; Blaha, V.; Chem.-Biol. Interact. 2007, 165, 14.

117. Kuca, K.; Jun, D.; Cabal, J.; Hrabinova, M.; Bartosova, L.; Opletalova, V.; Basic Clin. Phamarcol. Toxicol. 2006, 98, 389.

118. Taylor, P.; Wong, L.; Radic, Z.; Tsigelny, I.; Brüggemann, R.; Hosea, N. A.; Berman, H. A.; Chem.-Biol. Interact. 1999, 119-120, 3.

119. Ordentlich, A.; Barak, D.; Sod-Moriah, G.; Kaplan, D.; Mizrahi, D.; Segall, Y.; Kronman, C.; Karton, Y.; Lazar, A.; Marcus, D.; Velan, B.; Shafferman, A.; Chem.-Biol. Interact. 2005, 157-158, 191.

120. Ordentlich, A.; Barak, D.; Kronman, C.; Benschop, H. P.; De Jong, L. P. A.; Ariel, N.; Barak, R.; Segall, Y.; Velan, B.; Shafferman, A.; Biochemistry 1999, 38, 3055.

121. Ekström, F.; Akfur, C.; Tunemalm, A.-K.; Lundberg, S.; Biochemistry 2006, 45, 74.

122. Ekström, F.; Pang, Y.-P.; Boman, M.; Artursson, E.; Akfur, C.; Börjegren, S.; Biochem. Pharmacol. 2006, 72, 597.

123. Yang, Y.-C.; Baker, J. A.; Ward, J. R.; Chem. Rev. 1992, 92, 1729
124. Yang, Y.-C.; Acc. Chem. Res. 1999, 32, 109.

125. Morales-Rojas, H.; Moss, R. A.; Chem. Rev. 2002, 102, 2497.

126. Smith, B. M.; Chem. Soc. Rev. 2008, 37, 470.

127. Jokanovic, M.; Stojiljkovic, M. P.; Eur. J. Pharmacol. 2006, 553,10 .

128. McDonough, J. H.; Shih, T.-M. In Chemical Warfare Agents-Toxicology and Treatment; Marrs, T. C.; Maynard, R. L; Sidell, F. R., eds., $2^{\text {nd }}$ ed., John Wiley \& Sons Ltd: West Sussex, 2007, pp. 287-303.

129. Dunn, M. A.; Hackley, B. E.; Sidell, F. R. In Medical Aspects of Chemical and Biological Warfare-Textbook of Military Medicine; Sidell, F.R.; Takafuji, E. T.; Franz, D. R., eds.; Office of the Surgeon General, US Army: Washington D.C., 1997, pp. 181-196.

130. Eckert, S.; Eyer, P.; Mückter, H.; Worek, F.; Biochem. Pharmacol. 2006, 72, 344.

131. Scott, L. In Chemical Warfare Agents-Toxicology and Treatment; Marrs, T. C.; Maynard, R. L.; Sidell, F. R., eds., $2^{\text {nd }}$ ed., John Wiley \& Sons Ltd: West Sussex, 2007, pp. 343-353.

132. Bajgar, J.; J. Med. Chem. Def. 2004, 1, 1.

133. Layish, I.; Krivoy, A.; Rotman, E.; Finkelstein, A.; Tashma, Z.; Yehezkelli, Y.; Isr. Med. Assoc. J. 2005, 7, 182.

134. Doctor, B. P.; Saxena, A.; Chem.-Biol. Interact. 2005, 157-158, 167.

135. Lenz, D. E.; Yeung, D.; Smith, J. R.; Sweeney, R. E.; Lumley, L. A.; Cerasoli, D. M.; Toxicology 2007, 233, 31.

136. Evron, T.; Geyer, B. C.; Cherni, I.; Muralidharan, M.; Kilbourne, J.; Fletcher, S. P.; Soreq, H.; Mor, T. S.; FASEB J. 2007, 21, 2961.

137. Huang, Y.-J.; Huang, Y.; Baldasarre, H.; Wang, B.; Lazaris, A.; Leduc, M.; Bilodeau, A. S.; Bellemare, A.; Côté, M.; Herskovits, P.; Touati, M.; Turcotte, C.; Valeanu, L.; Lemée, N.; Wilgus, H.; Bégin, I.; Bhatia, B.; Rao, K.; Neveu, N.; Brochu, E.; Pierson, J.; Hockley, D. K.; Cerasoli, D. M.; Lenz, D. E.; Karatzas, C. N.; Langermann, S.; Proc. Natl. Acad. Sci. U. S. A. 2007, 104, 13603.

138. Rochu, D.; Chabrière, E.; Masson, P.; Toxicology 2007, 233,47

139. Vrdoljak, A. L.; Calic, M.; Radic, B.; Berend, S.; Jun, D.; Kuca, K.; Kovaric, Z.; Toxicology 2006, 228, 41.

140. Petroianu, G. A.; Lorke, D. E.; Hasan, M.Y.; Adem, A.; Sheen, R.; Nurulain, S. M.; Kalasz, H.; J. Appl. Toxicol. 2007, 27, 350.

141. Lorke, D. E.; Hasan, M. Y.; Nurulain, S. M.; Sheen, R.; Kuca, K.; Petroianu, G. A.; J. Appl. Toxicol. 2007, 27, 482.

142. Lorke, D. E.; Kalasz, H.; Petroianu, G. A.; Tekes, K.; Curr. Med. Chem. 2008, 15, 743.

143. Eyer, P. A.; Worek, F. In Chemical Warfare AgentsToxicology and Treatment; Marrs, T. C.; Maynard, R. L.; Sidell, F. R., eds., $2^{\text {nd }}$ ed., John Wiley \& Sons Ltd: West Sussex, 2007, pp. 305-329. 
144. Worek, F.; Reiter, G.; Eyer, P.; Szinicz, L.; Arch. Toxicol. 2002, 76, 523.

145. Kassa, J.; J. Toxicol.- Clin. Toxicol. 2002, 40, 803.

146. Kassa, J.; Jun, D.; Kuca, K.; Bajgar, J.; Basic Clin. Pharmacol. Toxicol. 2007, 101, 328.

147. Ashani, Y.; Radic, Z.; Tsigelny, I.; Vellom, D. C.; Pickering, N. A.; Quinn, D. M.; Doctor, B. P.; Taylor, P.; J. Biol. Chem. 1995, 270, 6370 .

148. Castro, A. T.; Figueroa-Villar, J. D.; Int. J. Quantum Chem. 2002, 89, 135.

149. Silva, G. R.; Borges Jr., I.; Figueroa-Villar, J. D.; Int. Quant. Chem. 2005, 105, 260.

150. Wong, L.; Radic, Z.; Brüggemann, R. J. M.; Hosea, N.; Berman, H. A.; Taylor, P.; Biochemistry 2000, 39, 5750.

151. Luo, C.; Saxena, A.; Smith, M.; Garcia, G.; Radic, Z.; Taylor, P.; Doctor, B. P.; Biochemistry 1999, 38, 9937.

152. Ashani, Y.; Bhattacharjee, A. K.; Leader, H.; Saxena, A.; Doctor, B. P.; Biochem. Pharmacol. 2003, 66, 191.

153. Worek, F.; Eyer, P.; Kiderlen, D.; Thiermann, H.; Szinicz, L.; Arch. Toxicol. 2000, 74, 21.

154. Kiderlen, D.; Worek, F.; Klimmek, R.; Eyer, P.; Arch. Toxicol. 2000, 74, 27.

155. Ekström, F. J.; Astot, C.; Pang, Y.-P.; Clin. Pharmacol. Ther. 2007, 82, 282.

156. Worek, F.; Aurbek, N.; Koller, M.; Becker, C.; Eyer, P.; Thiermann, H.; Biochem. Pharmacol. 2007, 73, 1807.

157. Lucic, A.; Radic, B.; Peraica, M.; Mesic, M.; Primozic, I.; Binenfeld, Z.; Arch. Toxicol. 1997, 71, 467.

158. Pang, Y.-P.; Kollmeyer, T. M.; Hong, F.; Lee, J.-C.; Hammond, P. I.; Haugabouk, S. P; Brimijoin, S.; Chem. Biol. 2003, 10, 491.

159. Kim, T.; Kuca, K.; Jun, D.; Jung, Y.; Bioorg. Med. Chem. Lett. 2005, 15, 2914.

160. Kuca, K.; Bartosova, L.; Kassa, J.; Cabal, J.; Bajgar, J.; Kunesova, G.; Jun, D.; Ext. Abstr. / Chem.-Biol. Interact. 2005, 157-158, 367.

161. Calic, M.; Vrdoljak, A. L.; Radic, B.; Jelic, D.; Jun, D.; Kuca, K.; Kovarik, Z.; Toxicology 2006, 219, 85.
162. Kuca, K.; Jun, D.; Kim, T.; Cabal, J.; Jung, Y.; Bull. Korean Chem. Soc. 2006, 27, 395.

163. Vrdoljak, A. L.; Lovric, J.; Radic, B.; Zlender, V.; Basic Clin. Pharmacol. Toxicol. 2006, 99, 17.

164. Kassa, J.; Karasova, J.; Toxicology 2007, 229, 136.

165. Kuca, K.; Jun, D.; Cabal, J.; Musilova, L.; Basic Clin. Pharmacol. Toxicol. 2007, 101, 25.

166. Musilek, K.; Holas, O.; Jun, D.; Dohnal, V.; Gunn-Moore, F.; Opletalova, V.; Dolezal, M.; Kuca, K.; Bioorg. Med. Chem. 2007, 15, 6733.

167. Musilek, K.; Jun, D.; Cabal, J.; Kassa, J.; Gunn-Moore, F.; Kuca, K.; J. Med. Chem. 2007, 50, 5514.

168. Acharya, J.; Gupta, A. K.; Mazumder, A.; Dubey, D. K.; Toxicol. in Vitro 2008, 22, 525.

169. Jun, D.; Kuca, K.; Picha, J.; Koleckar, V.; Marek, J.; Drug Chem. Toxicol. 2008, 31, 1.

170. Kassa, J.; Karasova, J.; Musilek, K.; Kuca, K.; Toxicology 2008, 243, 311.

171. Van Helden, H. P. M.; Busker, R. W.; Melchers, B. P. C.; Bruijnzeel, P. L. B.; Arch. Toxicol. 1996, 70, 779.

172. Eyer, P.; Toxicol. Rev. 2003, 22, 165.

173. Eddleston, M.; Buckley, N. A.; Eyer, P.; Dawson, A. H.; Lancet 2008, 371, 597.

174. Hmouda, H.; Salem, C. B.; Bouraoui, K.; Lancet 2008, $371,2169$.

175. Eddleston, M.; Dawson, A. H.; Buckley, N. A.; Lancet 2008, 371, 2170 .

176. Kuca, K.; Jun, D.; Musilek, K.; Mini-Rev. Med. Chem. 2006, 6, 269.

177. Buncel, E.; Cannes, C.; Chatrousse, A.-P.; Terrier, F.; J. Am. Chem. Soc. 2002, 124, 8766.

178. Terrier, F.; Rodriguez-DaFonte, P.; Le Guével, E.; Moutiers, G.; Org. Biomol. Chem. 2006, 4, 4352.

Received: October 23, 2008 Web Release Date: March 6, 2009 